\title{
De psychische gezondheid van gedetineerden in België en Nederland: een systematisch overzicht
}

\author{
Louis Favril \& Anja Dirkzwager
}

Internationaal onderzoek toont consistent aan dat psychische gezondheidsproblemen (psychiatrische stoornissen, psychische klachten en middelengebruik) disproportioneel vaker voorkomen bij gedetineerden in vergelijking met de algemene bevolking. Een slechte psychische gezondheid gaat gepaard met verschillende ongunstige uitkomsten, waaronder suïcide. In de afgelopen jaren werden veel nieuwe Belgische en Nederlandse gegevens over dit thema gepubliceerd in de wetenschappelijke literatuur, die tot op heden niet werden gebundeld. In deze systematische literatuurstudie wordt een up-todate overzicht gegeven van onderzoeksbevindingen omtrent de omvang van psychische problemen bij gedetineerden in België en Nederland. Gebaseerd op 24 empirische studies uitgevoerd in 1997-2018 blijkt dat personen met psychische problemen oververtegenwoordigd zijn in Belgische en Nederlandse gevangenissen. Dit vormt zowel een uitdaging als een opportuniteit om tegemoet te komen aan de zorgbehoeften van deze kwetsbare populatie. Investeren in de preventie en behandeling van psychische problemen komt niet alleen de gedetineerden in kwestie ten goede, maar evenzeer de maatschappij in brede zin.

\section{Inleiding}

Op elk willekeurig moment zijn wereldwijd grofweg 10 miljoen personen opgesloten in een gevangenis. ${ }^{1}$ Op 1 september 2016 waren in België en Nederland samen ongeveer 19.000 volwassenen gedetineerd (tabel 1). Er is reeds veelvuldig onderzoek uitgevoerd naar de algemene gezondheidstoestand van gedetineerden (Kinner \& Young, 2018), bijvoorbeeld in Duitsland (Opitz-Welke e.a., 2018), Canada (Kouyoumdjian e.a., 2016), de Verenigde Staten (Wilper e.a., 2009) en het Verenigd Koninkrijk (Heidari e.a., 2014). Uit deze - overwegend Angelsaksische literatuur komen duidelijke aanwijzingen dat de lichamelijke gezondheid van gedetineerden slechter is dan die van de algemene bevolking. De prevalentie van infectieziekten (hiv, hepatitis en tuberculose) en chronische aandoeningen (diabetes, astma en hypertensie) is bijvoorbeeld erg hoog onder diegenen die zijn opgesloten in een gevangenis (Dolan e.a., 2016; Fazel \& Baillargeon, 2011).

1 De term gevangenis verwijst naar alle penitentiaire inrichtingen waar justitiabelen verblijven en omvat dus zowel de huizen van bewaring als gevangenissen (in België respectievelijk arresthuizen en strafhuizen). Gedetineerde wordt als algemene term aangewend in het artikel en heeft betrekking op elke persoon die is opgesloten in een gevangenis zonder daarbij naar een specifiek juridische titel (preventief gehechten en veroordeelden) te verwijzen, tenzij anders vermeld. 
Tabel 1 Het gevangeniswezen in cijfers, België en Nederland (2016)

\begin{tabular}{lll}
\hline & België & Nederland \\
\hline Detentieratio $^{\mathrm{a}}$ & 93,6 & 49,8 \\
Penitentiaire inrichtingen & 35 & 30 \\
Capaciteit & 9.727 & 10.688 \\
Gedetineerdenpopulatie & 10.583 & 8.457 \\
Bezetting per 100 plaatsen & 108,8 & 79,1 \\
Voorlopige hechtenis (\%) & 29,2 & 43,6 \\
Vrouwen (\%) & 4,3 & 5,3 \\
Gemiddelde leeftijd & 36 & 35 \\
\hline
\end{tabular}

Bron: Council of Europe (Aebi e.a., 2017).

${ }^{a}$ Het aantal gedetineerden per 100.000 inwoners.

Internationaal onderzoek naar de psychische gezondheid van gedetineerden, hetgeen de focus van het huidige artikel vormt, wijst ook consistent in één richting. Psychiatrische stoornissen, psychische klachten en middelengebruik - alle indicatoren voor een slechte psychische gezondheid - blijken oververtegenwoordigd te zijn binnen de muren van de gevangenis (Andersen, 2004; Fazel e.a., 2016; Franke e.a., 2019). Een consistente bevinding is bijvoorbeeld dat psychiatrische stoornissen, inclusief verslaving, meer frequent zijn onder de populatie van gedetineerden dan wat men zou verwachten bij een vergelijkbare populatie buiten de gevangenis (Bebbington e.a., 2017; Butler e.a., 2006; Fazel \& Danesh, 2002; Indig e.a., 2016; Prins, 2014). De klinische en beleidsmatige relevantie hiervan is groot; psychische problemen zijn namelijk geassocieerd met verschillende ongunstige gevolgen, zoals functionele beperkingen, agressief gedrag, slachtofferschap en recidive (Fazel e.a., 2016). Onderzoek duidt bovendien op een nauwe relatie tussen psychische gezondheidsproblemen en voortijdig overlijden, in het bijzonder door suïcide (Chesney e.a., 2014). Verschillende internationale richtlijnen benadrukken dan ook de noodzaak om psychische problemen onder gedetineerden aan te pakken, met als finaliteit de negatieve gevolgen ervan te beperken (NICE, 2017; WHO, 2014).

\section{Verklarend model}

Het feit dat de psychische gezondheid van gedetineerden beduidend slechter is dan die van hun tegenhangers in de vrije maatschappij heeft de wetenschappelijke discussie over mogelijke verklaringen hiervoor gestimuleerd. De oververtegenwoordiging van psychische problemen bij gedetineerden ten opzichte van de doorsnee maatschappij impliceert dat iets specifiek aan detentie - hetzij de gevangeniscontext, hetzij de personen daarbinnen - hieraan ten grondslag ligt. Anders geformuleerd: is de hoge prevalentie van psychische problemen in detentie een reflectie van de reeds bestaande problematiek bij personen die er worden opgesloten, dan wel een gevolg van de opsluiting? Een eenduidig antwoord op deze vraag zou tenietdoen aan de complexiteit van de relatie tussen psychische gezondheid en detentie (Schnittker e.a., 2012). De hoge prevalentie van psychi- 
sche problemen bij gedetineerden kan immers vanuit twee perspectieven worden verklaard: het import- en het deprivatiemodel. Enerzijds blijkt de grens tussen de vrije samenleving (extra muros) en de gevangenis (intra muros) in het bijzonder permeabel voor personen met psychische problemen, wier gedrag hen niet zelden onder de aandacht van het strafrechtsysteem brengt. Gegeven het duidelijke, doch niet noodzakelijk causale, verband tussen psychische problemen en het plegen van criminaliteit (Bennett e.a., 2008; Copeland e.a., 2007; Fazel e.a., 2015; Fovet e.a., 2015; Morgan e.a., 2013; Prince \& Wald, 2018; Stevens e.a., 2015; Yu e.a., 2012) worden personen met dergelijke problemen vaker opgesloten in een gevangenis. De psychische problemen zijn in dit geval reeds aanwezig vóór de detentie - niet zelden gelieerd aan het misdrijf - en worden vervolgens door de persoon in de gevangenis geïmporteerd wanneer hij of zij er wordt opgesloten. Anderzijds wordt beargumenteerd dat detentie an sich negatieve effecten kan bewerkstelligen op de psychische gezondheid van gedetineerden. De 'pains of imprisonment' en de blootstelling aan de stressvolle aspecten van het leven in detentie (zoals het verlies van vrijheid en autonomie, het wegvallen van steunfiguren, conflicten, agressie, overbevolking en het gebrek aan zinvolle tijdsbesteding) verhogen de kans dat gedetineerden psychische problemen ontwikkelen gedurende de opsluiting, of dat reeds bestaande aandoeningen verslechteren (Birmingham, 2003; Edgemon \& Clay-Warner, 2019; Goomany \& Dickinson, 2015; Jablonska \& Meek, 2018; Nurse e.a., 2003). Eerder dan een of-ofverhaal onderstreept het bestaande empirische onderzoek dat de interactie tussen het individu (importfactoren) en de detentiecontext (deprivatiekenmerken) het beste in staat is om de psychische gezondheid van gedetineerden te verklaren (Armour, 2012; Brons e.a., 2013; Fedock, 2017; Gillespie, 2005; Gonçalves e.a., 2016; Slotboom e.a., 2009; Vandebosch, 2002).

\section{Relevantie en doel van het onderzoek}

Het doel van het huidige artikel is een overzicht te bieden van psychische gezondheidsproblemen bij gedetineerden in België en Nederland. Dit is relevant omwille van verschillende redenen. Zo stamt het gros van de bestaande literatuur naar het vóórkomen van psychische problemen bij gedetineerden van Angelsaksische bodem. Een belangrijke vraag is echter in hoeverre deze internationale bevindingen - gebaseerd op landen met hun eigen specifieke detentiecondities en zorgsystemen - te generaliseren zijn naar de situatie in de Lage Landen. Hoewel België en Nederland naast een geografische grens heel wat gelijkenissen vertonen als het gaat om demografische, sociaaleconomische en linguïstische factoren, alsmede qua psychische gezondheid, ${ }^{2}$ bestaan er ook aanzienlijke verschillen qua penitentiair beleid, gevangenispopulatie en -capaciteit (Beyens e.a., 2014; zie tabel 1). Door de literatuur van beide landen te onderzoeken kunnen we meer inzicht verkrijgen in hoeverre er verschillen dan wel overeenkomsten zijn tussen België en Nederland.

2 Epidemiologisch onderzoek toont aan dat psychische problemen in gelijke mate voorkomen in de algemene Belgische en Nederlandse bevolking (Kessler e.a., 2009; Reynders e.a., 2016). 
Verder ontbreekt tot op heden een systematische synthese van Belgisch onderzoek naar de prevalentie van psychische gezondheidsproblemen bij gedetineerden. ${ }^{3}$ Hoewel in Nederland wel eerder literatuuronderzoek is uitgevoerd naar de psychische gezondheid van gedetineerden (Bulten e.a., 1999; Dirkzwager e.a., 2009), zij het op niet-systematische wijze, zijn de bevindingen van deze onderzoeken inmiddels gedateerd; het meest recente onderzoek includeerde studies tot oktober 2008. In het afgelopen decennium zijn echter veel nieuwe Nederlandse (en Belgische) onderzoeksgegevens over dit thema gepubliceerd in de wetenschappelijke literatuur, waardoor een update aangewezen is (Fazel, 2018). Bovendien is in de Lage Landen nooit eerder een systematisch literatuuronderzoek uitgevoerd naar psychische problemen bij specifieke populaties van gedetineerden, zoals vrouwen en ouderen, terwijl buitenlands onderzoek aantoont dat zulke groepen bijzonder kwetsbaar zijn qua psychische gezondheid (Fazel e.a., 2016; Franke e.a., 2019; Watson e.a., 2004; WHO, 2014).

Een synthese van recent wetenschappelijk onderzoek naar de omvang van psychische problemen onder gedetineerden in België en Nederland is dus niet voorhanden. Een gedegen en actueel inzicht in de psychische problematiek bij gedetineerden is nochtans beleidsmatig relevant omdat het kan bijdragen aan het beter inschatten van de zorgbehoeften van gedetineerden en de benodigde geestelijke gezondheidszorg in detentie, en aldus aanknopingspunten kan bieden voor preventie, begeleiding en interventie (NICE, 2017; Verdot e.a., 2015). Dit alles onderbouwt het doel van het huidige artikel: een systematisch en up-to-date overzicht bieden van onderzoeksbevindingen omtrent de omvang van psychische gezondheidsproblemen bij gedetineerden in België en Nederland, met bijzondere aandacht voor kwetsbare groepen (vrouwelijke en oudere gedetineerden) en suïcidaliteit als ongunstige uitkomst van psychische problemen.

\section{Methode}

\section{Databronnen en zoekstrategie}

Om een overzicht te krijgen van Belgisch en Nederlands prevalentieonderzoek naar psychische problemen en suïcidaliteit bij gedetineerden zijn diverse elektronische databanken geraadpleegd. Zo zijn Web of Science en PubMed doorzocht om (internationale) wetenschappelijke publicaties op te sporen, alsook Google Scholar om zogenoemde 'grijze literatuur' (zoals onderzoeksrapporten) te vinden. Daarnaast zijn de belangrijkste Nederlandse (Tijdschrift voor Criminologie, Proces, Verslaving en Tijdschrift voor Psychiatrie) en Belgische (Panopticon en Fatik) tijdschriften handmatig doorzocht. Bij het doorzoeken van deze bronnen hanteerden we een combinatie van relevante zoektermen die betrekking hebben op de psychische gezondheid (mental OR health OR psych* OR disord* OR distress OR drug* OR substance OR medica* OR psychotrop* OR suicid*), de populatie van gedetineerden (prison* OR detain* OR jail OR offend*) en de geografische setting (Belgi*

3 Een eerdere overzichtsstudie (2006-2016; Witkowski e.a., 2017) beschreef de algemene gezondheid, zorgbehoeften en hulpverlening bij gedetineerden en geïnterneerden in België (met inclusie van kwalitatief onderzoek). 
OR Flanders OR Netherlands OR Dutch). Deze zoektermen werden eveneens in het Nederlands ingevoerd. Tot slot zijn de referentielijsten van relevante publicaties gescreend om aanvullende publicaties te identificeren.

\section{Inclusie- en exclusiecriteria}

We zochten naar Belgische en Nederlandse (prevalentie)studies die tussen januari 1997 en augustus 2018 in wetenschappelijke tijdschriften of onderzoeksrapporten zijn verschenen. Voor deze overzichtsstudie zijn psychische gezondheidsproblemen geoperationaliseerd als psychiatrische stoornissen, psychische klachten, verslaving/middelengebruik en psychofarmaca op voorschrift. Suïcidaliteit, als mogelijke uitkomst van psychische problemen, werd eveneens opgenomen in het zoekproces. Hierbij werden a priori verschillende criteria tot inclusie vooropgesteld. Een eerste inclusiecriterium was dat de kwantitatieve studies gebaseerd waren op origineel empirisch onderzoek en data rapporteerden over een (of meer) van voornoemde indicatoren of suïcidaliteit. Ten tweede, qua onderzoekspopulatie, zijn uitsluitend studies geïncludeerd die volwassen gedetineerden ( $\geq 18$ jaar) op de reguliere afdelingen van penitentiaire inrichtingen onderzochten. Specifieke steekproeven (zoals uitsluitend gedetineerden met verslavingsproblemen of psychiatrische stoornissen) werden dus niet opgenomen aangezien deze een vertekend beeld van prevalentiecijfers geven. Dit betekent dat uitsluitend studies zijn geïncludeerd waarvan de steekproef (idealiter op volledig willekeurige wijze) uit de algemene gedetineerdenpopulatie werd geselecteerd. Vanwege die reden zijn studies specifiek gericht op tbs'ers (Nederland), geïnterneerden (België) of forensische patiënten dan ook niet geïncludeerd aangezien zij selectieve klinische groepen betreffen (Völlm e.a., 2018). Ook arrestanten in politiecellen en jeugdige delinquenten (minderjarigen) vielen buiten de scope van het huidige artikel. Ten derde werden kwalitatieve studies naar de detentiebeleving in algemene zin (voor een overzicht, zie Beyens e.a., 2014) en evaluaties van specifieke interventies of behandelingen uitgesloten. Samenvattend includeerden we enkel kwantitatieve studies die psychische problemen en suïcidaliteit onderzochten bij niet-selectieve steekproeven van volwassenen op de reguliere afdelingen van penitentiaire inrichtingen.

\section{Resultaten van het zoekproces}

$\mathrm{Na}$ een grondige screening op basis van titels en abstracts werden 98 potentieel relevante studies geïdentificeerd. Nadat deze studies volledig waren doorgenomen, bleken er 61 niet te voldoen aan een of meer van de inclusiecriteria. Onder de 37 studies die vatbaar waren voor inclusie werd in enkele gevallen hetzelfde onderzoek beschreven; dit resulteerde in 13 dubbelpublicaties ${ }^{4}$ (appendix). In deze gevallen waren de criteria tot inclusie, in aflopende volgorde: (1) de meest omvattende beschrijving van het onderzoek, (2) publicatie na peer review en (3) Nederlandstalige publicatie. Alles samen werden, op basis van onze stringente inclusiecriteria, 24 unieke empirische studies geïdentificeerd.

4 Dit waren bijvoorbeeld onderzoeksrapporten die nadien werden gepubliceerd in een wetenschappelijk tijdschrift, of dubbelpublicaties van eenzelfde onderzoek in zowel een Nederlandstalig als een Engelstalig tijdschrift. 


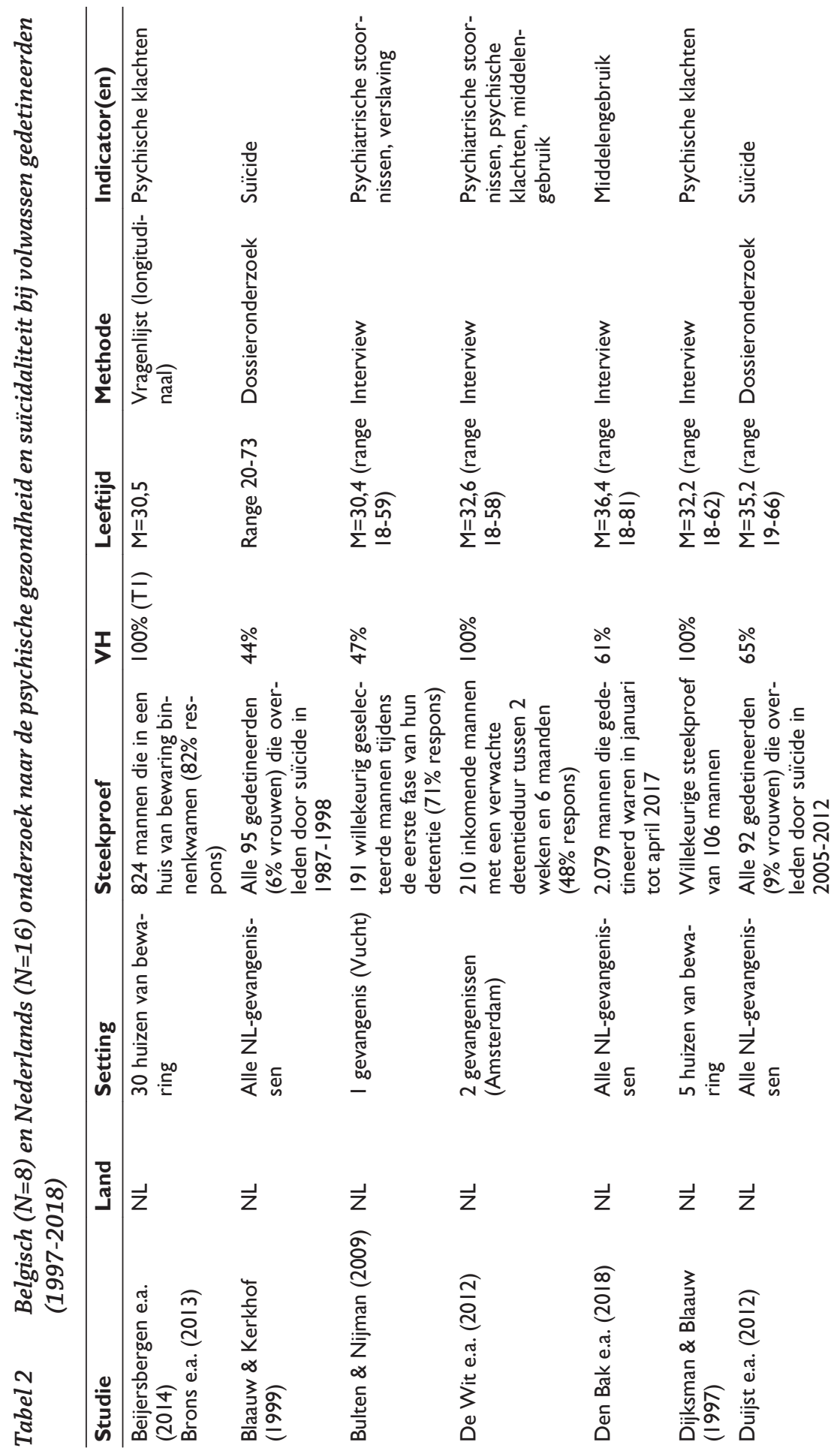




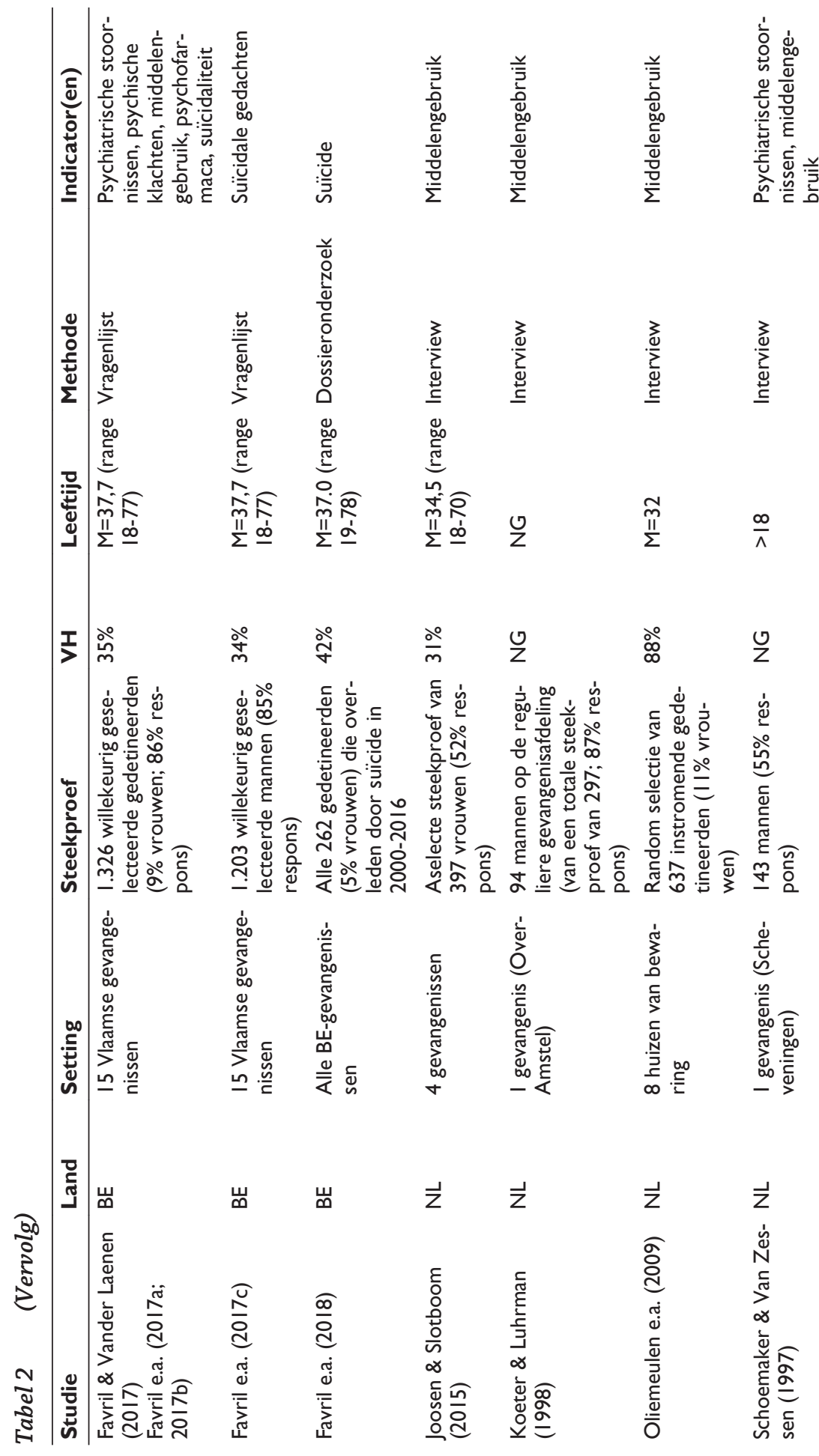




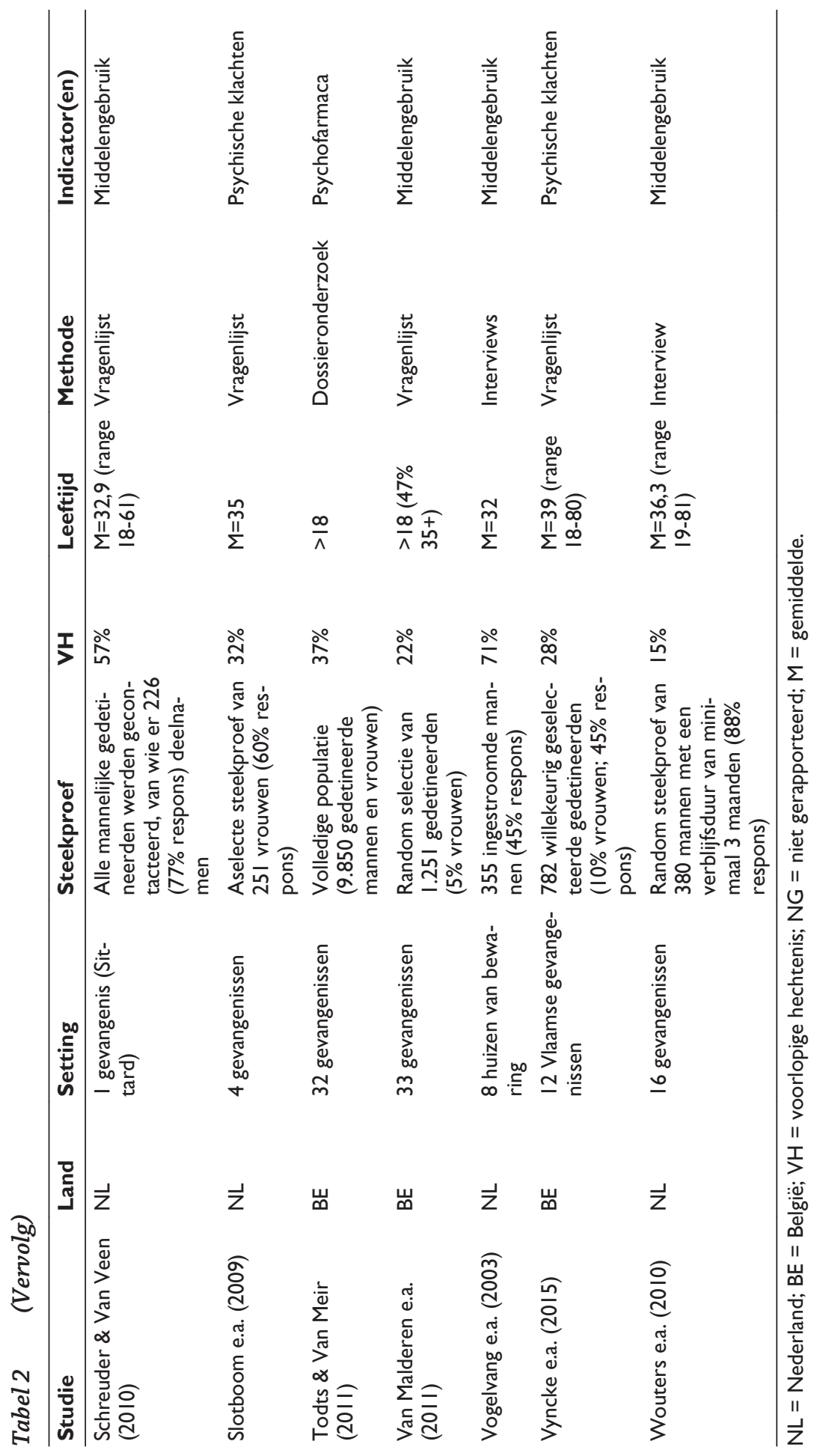




\section{Kenmerken van de studies}

In totaal werden 24 studies geïncludeerd in het huidige overzicht, waarvan er twee op drie $(\mathrm{N}=16)$ in Nederland werden uitgevoerd (tabel 2). De steekproefgroottes varieerden van 92 tot 9.850 gedetineerden. In de helft van alle studies $(\mathrm{N}=12)$ werden enkel mannen onderzocht en in slechts twee studies (beide van Nederlandse bodem) waren uitsluitend vrouwen het onderwerp van het onderzoek. In de overige tien studies waar beide geslachten vertegenwoordigd waren, bedroeg het percentage vrouwen gemiddeld genomen $8 \%$ (range 5 tot $11 \%$ ), hetgeen een goede afspiegeling vormt van de werkelijke verdeling in de gevangenissen $^{5}$ (tabel 1). De leeftijd van de gedetineerden varieerde van 18 tot 81 jaar. Waar gerapporteerd, schommelde de gemiddelde leeftijd tussen 30,4 en 37,7 jaar, wat opnieuw overeenkomt met de totale Belgische en Nederlandse gedetineerdenpopulatie (tabel 1). In de studies waren alle soorten delicten vertegenwoordigd; het merendeel selecteerde de steekproeven op willekeurige wijze (alle onafhankelijk van type delict). De meeste studies hadden een crosssectioneel onderzoeksdesign; er waren slechts twee longitudinale studies (die bovendien dezelfde Nederlandse onderzoekspopulatie betroffen). Qua onderzoeksmethode hanteerden de studies ofwel een dossieronderzoek $(\mathrm{N}=4)$, ofwel interviews en/of vragenlijsten $(\mathrm{N}=20)$. Overkoepelend werd verslaving/middelengebruik het meest frequent onderzocht $(\mathrm{N}=12)$, gevolgd door psychische klachten $(\mathrm{N}=7)$, suïcidaliteit $(\mathrm{N}=5)$, psychiatrische stoornissen $(\mathrm{N}=4)$ en het gebruik van psychofarmaca $(\mathrm{N}=2)$. Opgeteld is dit aantal hoger dan 24, omdat enkele studies meerdere indicatoren voor psychische gezondheidsproblemen en/of suïcidaliteit onderzochten.

\section{Resultaten}

In wat volgt wordt een overzicht gegeven van de bevindingen voor wat betreft de prevalentie van psychische gezondheidsproblemen bij gedetineerden in België en Nederland, geoperationaliseerd als (1) psychiatrische stoornissen, (2) psychische klachten, (3) verslaving/middelengebruik en (4) het gebruik van psychofarmaca. Vervolgens wordt aandacht besteed aan (5) specifieke subpopulaties (vrouwelijke en oudere gedetineerden) en (6) suïcidaliteit als mogelijke ongunstige uitkomst van psychische problemen. Voor elk van deze zes thema's worden de bevindingen van de Belgische en Nederlandse studies telkens in de context geplaatst van de recente internationale literatuur.

\section{Psychiatrische stoornissen}

Hoewel systematische overzichtsstudies de prevalentie van psychiatrische stoornissen bij gedetineerden (voornamelijk in westerse landen) onderzochten (tabel 3), worden erg uiteenlopende cijfers gerapporteerd in de internationale literatuur

5 Enkele studies kozen er expliciet voor om het aantal vrouwelijke participanten te oversampelen. Dit houdt in dat meer vrouwen werden bevraagd dan dat er zich proportioneel in de (Belgische) gevangenissen bevinden. Op deze manier is de steekproef vrouwen voldoende groot om betrouwbare uitspraken te doen over de resultaten van de vrouwelijke gedetineerden als subpopulatie, en om statistische vergelijkingen met mannelijke gedetineerden mogelijk te maken. 
Tabel 3 Puntprevalentie van psychiatrische stoornissen bij gedetineerden volgens systematische overzichtsstudies ${ }^{a}$

\begin{tabular}{llll}
\hline Stoornis & Mannen & Vrouwen & Referentie \\
\hline Psychotische stoornis & $4(3-4)$ & $4(3-5)$ & Fazel \& Seewald (20I2) \\
Depressieve stoornis & $10(9-12)$ & $14(10-18)$ & Fazel \& Seewald (20I2) \\
PTSS & $6(4-9)$ & $21(17-26)$ & Baranyi e.a. (20I8) \\
Alcoholverslaving & $26(23-30)$ & $20(16-24)$ & Fazel e.a. (20I7b) \\
Drugsverslaving & $30(22-38)$ & $5 I(43-58)$ & Fazel e.a. (20I7b) \\
Persoonlijkheidsstoornis & $65(6 I-68)$ & $42(38-45)$ & Fazel \& Danesh (2002) \\
\hline
\end{tabular}

a Prevalentiecijfers zijn percentages met $95 \%$ betrouwbaarheidsinterval.

b Posttraumatische stressstoornis.

(Andersen, 2004; Birmingham, 2003; Fazel e.a., 2016; Gottfried \& Christopher, 2017; Sirdifield e.a., 2009). Deze heterogeniteit in prevalentiecijfers is voornamelijk te wijten aan methodologische factoren, ${ }^{6}$ waarmee we rekening moeten houden wanneer Belgische en Nederlandse studies onder de loep worden genomen.

Van de 24 geïdentificeerde studies in België en Nederland werd de prevalentie van psychiatrische stoornissen in vier gevallen onderzocht (tabel 2). In het enige Belgische onderzoek werden 1.326 gedetineerden ( $91 \%$ mannen) uit vijftien Vlaamse gevangenissen bevraagd naar gediagnosticeerde stoornissen over de levensloop. Iets minder dan de helft (46\%) gaf aan ooit een formele diagnose van een psychiatrische stoornis te hebben gekregen; bij een vierde (24\%) van de totale steekproef was zelfs sprake van twee of meer verschillende diagnoses (Favril e.a., 2017a). Belangrijk om op te merken is dat deze studie betrekking heeft op (zelfgerapporteerde) diagnoses over de levensloop, eerder dan huidige stoornissen. Een dergelijke aanpak kan echter een onderschatting van de werkelijke omvang van psychiatrische stoornissen impliceren. Gegeven de reële kans op onderdiagnosticering bij gedetineerden (Howerton e.a., 2007) sluit dit immers diegene uit met een psychiatrische stoornis, maar zonder een formele diagnose. Aan deze beperking werd tegemoetgekomen door Bulten en Nijman (2009), die psychiatrische interviews afnamen bij 191 mannelijke gedetineerden in de gevangenis van Vught. Door middel van gevalideerde meetinstrumenten werden door de onderzoekers diagnoses (al dan niet voor de eerste maal) vastgesteld aan de hand van de DSMIII-R-criteria. Het bleek dat ongeveer vier op de vijf (82\%) van de willekeurig geselecteerde gedetineerden ooit eerder een psychiatrische diagnose had, verslaving meegerekend. Bij meer dan de helft (57\%) van de steekproef was sprake van een psychiatrische stoornis op het moment van het diagnostisch interview (Bulten \& Nijman, 2009). De overige twee Nederlandse studies bevestigen dit beeld en von-

6 Methodologische verschillen omvatten bijvoorbeeld variërende operationele definities (stoornis vs. diagnose), tijdsperiodes (huidig vs. lifetime) en meetinstrumenten (zelfrapportage vs. diagnostisch interview), alsook de geringe vergelijkbaarheid tussen (soms niet-representatieve) steekproeven. Deze verschillen beperken de externe validiteit en generaliseerbaarheid, waardoor het geen sinecure is om prevalentiecijfers op eenduidige wijze te vergelijken tussen studies en landen. 
den eveneens dat circa de helft van de geïnterviewde gedetineerden ten tijde van het onderzoek een psychiatrische stoornis had (De Wit e.a., 2012; Schoemaker \& Van Zessen, 1997).

\section{Psychische klachten}

Uit internationaal onderzoek komt naar voren dat naast psychiatrische stoornissen ook minder ernstige psychische klachten vaker voorkomen bij gedetineerden dan bij personen uit de algemene bevolking (Andersen, 2004; Bronson \& Berzofsky, 2017; Indig e.a., 2016). Daar waar psychiatrische stoornissen (idealiter) worden vastgesteld aan de hand van een klinisch interview, wordt de mate van subjectief (on)welbevinden veelal gemeten met behulp van screeningsinstrumenten via zelfrapportage. ${ }^{7}$

Zeven studies onderzochten psychische klachten onder gedetineerden in België en Nederland (tabel 2). Net als veelvuldig onderzoek van Nederlandse bodem (Brons e.a., 2013; De Wit e.a., 2012; Dijksman \& Blaauw, 1997; Slotboom e.a., 2009) toont een studie in twaalf Vlaamse gevangenissen aan dat slaapproblemen, angst, depressieve gevoelens en psychosomatische klachten frequent voorkomen onder 782 gedetineerden (Vyncke e.a., 2015). Tot eenzelfde conclusie kwam de eerdergenoemde Belgische studie die meer dan duizend gedetineerden bevroeg naar hun psychisch welbevinden; ernstige psychische klachten tijdens de detentie waren aanwezig bij meer dan een derde (37\%) van alle respondenten (Favril e.a., 2017a). Wanneer wordt vergeleken met de algemene bevolking komen de bovenstaande studies tot eenzelfde conclusie: psychische klachten komen (drie- tot vijfmaal) vaker voor binnen de muren van de gevangenis. Longitudinaal onderzoek bij Nederlandse mannelijke gedetineerden maakt verder duidelijk dat zelfgerapporteerde psychische klachten vooral voorkomen tijdens de eerste fase van detentie en met verloop van tijd afnemen (Dirkzwager \& Nieuwbeerta, 2018). Ook blijken zowel eigenschappen van de gedetineerden (zoals psychische problemen voor detentie, persoonlijkheid en copingstijl) als kenmerken van de detentieomgeving (zoals bejegening door het personeel, omgang met medegedetineerden en ervaren dagbesteding) van invloed te zijn op (het verloop van) psychische problemen tijdens de detentieperiode (Beijersbergen e.a., 2014; Brons e.a., 2013; Slotboom e.a., 2009).

\section{Verslaving en middelengebruik}

Wereldwijd zou bij grofweg een kwart (24\%) van de inkomende gedetineerden sprake zijn van een stoornis in het gebruik van alcohol, terwijl nog hogere cijfers (30 tot 50\%) worden gevonden voor wat betreft drugsverslaving (Fazel e.a., 2017b).

7 In de geïncludeerde studies werden verschillende meetinstrumenten gebruikt, waaronder de Brief Symptom Inventory (BSI), Symptom Checklist (SCL-90), General Health Questionnaire (GHQ-12) en Hospital Anxiety and Depression Scale (HADS). Deze screeningsinstrumenten zijn niet geschikt om klinische diagnoses te stellen, maar zijn indicatief voor de aanwezigheid van psychiatrische problematiek. 
In België en Nederland hebben acht studies zich gericht op verslavingsproblematiek bij gedetineerden (tabel 2). In de eerder besproken studie van Bulten en Nijman (2009) werden alcohol- en drugsverslaving vastgesteld bij respectievelijk $28 \%$ en $30 \%$ van de 191 mannelijke gedetineerden. In vier Nederlandse gevangenissen rapporteerde $20 \%$ van de 397 gedetineerde vrouwen een harddrugsverslaving over de levensloop, $15 \%$ een softdrugsverslaving en $14 \%$ een alcoholverslaving (Joosen \& Slotboom, 2015). In vijftien Vlaamse gevangenissen meldde verder een vierde $(25 \%)$ van alle respondenten $(\mathrm{N}=1.326)$ een lifetime diagnose van een middelengerelateerde stoornis (Favril \& Vander Laenen, 2017), waarbij afhankelijkheid van drugs tweemaal zo vaak werd gerapporteerd als afhankelijkheid van alcohol (respectievelijk $21 \%$ en $10 \%$ ). ${ }^{8}$ Uit een andere Nederlandse studie blijkt dat, in het jaar voorafgaand aan de detentie, bij 30\%en 38\% van de willekeurig geselecteerde gedetineerden $(\mathrm{N}=637)$ sprake was van respectievelijk problematisch alcohol- en druggebruik (Oliemeulen e.a., 2009). Deze gegevens komen sterk overeen met de resultaten van vier andere studies naar problematisch druggebruik in reguliere Nederlandse penitentiaire inrichtingen, namelijk 35\% problematisch druggebruik (De Wit e.a., 2012), 40\% probleemgebruikers (Vogelvang e.a., 2003), 44\% verslaafden (Koeter \& Luhrman, 1998) en 36\% afhankelijke gebruikers (Schoemaker \& Van Zessen, 1997). In deze laatste studie voldeed $29 \%$ in het afgelopen jaar aan de diagnostische criteria van drugafhankelijkheid.

Tevens is onderzoek gedaan naar het gebruik van drugs bij gedetineerden, los van eventuele stoornissen of verslavingsproblematiek. Talrijke internationale epidemiologische studies tonen aan dat druggebruik bij gedetineerden hoog is (Kinner $\&$ Rich, 2018). Naar schatting heeft ruim de helft van de globale gevangenispopulatie ooit een illegaal product gebruikt, en tijdens de detentieperiode meldt 20 tot $40 \%$ van de gedetineerden dergelijk middelengebruik (Carpentier e.a., 2012; Mundt e.a., 2018).

In België en Nederland hebben vier studies (injecterend) druggebruik bij gedetineerden onderzocht (tabel 2). Twee grootschalige studies in België tonen aan dat een op de drie gedetineerden (30 tot 35\%) illegale drugs of niet-voorgeschreven psychofarmaca gebruikt tijdens de huidige detentieperiode (Favril \& Vander Laenen, 2017; Van Malderen e.a., 2011). In Nederland worden vergelijkbare cijfers gevonden. In het onderzoek door Schreuder en Van Veen (2010) had een derde (36\%) van de 226 respondenten tijdens de detentie drugs gebruikt. Meer recent vond men in Nederland een prevalentie van $34 \%$ onder een representatieve steekproef van 2.079 mannelijke gedetineerden; bij 15\% van alle respondenten was sprake van 'ernstig' druggebruik (Den Bak e.a., 2018). Uit voorgaande studies blijken de meest gebruikte middelen gedurende de opsluiting, in aflopende volgorde: cannabis, heroïne en niet-voorgeschreven benzodiazepines (slaap- en kalmerings-

8 De discrepantie in prevalentiecijfers tussen enerzijds de studies die diagnoses vaststelden via een klinisch interview (Bulten \& Nijman, 2009; Fazel e.a., 2017b) en anderzijds de studies die verslavingen en diagnoses over de levensloop bevroegen via zelfrapportage (Favril \& Vander Laenen, 2017; Joosen \& Slotboom, 2015) kan een indicatie zijn voor het feit dat diagnoses bij gedetineerden vaak niet worden vastgesteld buiten de context van wetenschappelijk onderzoek. 
middelen). Deze middelen worden gekenmerkt door hun dempende werking en zijn congruent met de functies van druggebruik in detentie; het merendeel van de gedetineerden wil zich namelijk via middelengebruik ontspannen, hoopt problemen te vergeten of tracht verveling tegen te gaan (Van Malderen e.a., 2011). Met cijfers rond de $2 \%$ in zowel België als Nederland komt injecterend druggebruik relatief weinig voor in detentie (Schreuder \& Van Veen, 2010; Van Malderen e.a., 2011; Wouters e.a., 2010). Bij de interpretatie van voornoemde resultaten is het echter belangrijk om voor ogen te houden dat deze gebaseerd zijn op zelfgerapporteerde data, wat een mogelijke vertekening inhoudt. Het is namelijk mogelijk dat gedetineerden gevoelige informatie - druggebruik in detentie - onderrapporteren, bijvoorbeeld uit vrees voor disciplinaire sancties. Desondanks komen de prevalentiecijfers in de Lage Landen overeen met de cijfers uit eerder Europees onderzoek (Carpentier e.a., 2012).

\section{Psychofarmaca op voorschrift}

Net als (illegaal) druggebruik blijkt het gebruik van psychofarmaca op voorschrift hoog tijdens de detentieperiode. Grootschalig onderzoek uit Canada (Farrell MacDonald e.a., 2015) en Engeland (Hassan e.a., 2016) toont aan dat 20 tot $30 \%$ van de gedetineerden op een gegeven moment psychoactieve medicatie krijgt voorgeschreven tijdens hun detentie; vier- tot zesmaal zo vaak als bij personen van vergelijkbare leeftijd in de algemene bevolking.

Gegevens over het gebruik van psychofarmaca bij Nederlandse gedetineerden zijn niet voorhanden (tabel 2), maar twee Belgische studies stelden onafhankelijk van elkaar vast dat 36 tot 38\% van de gedetineerden in België minstens één soort psychofarmaca kreeg voorgeschreven op het moment dat het onderzoek plaatsvond (Favril \& Vander Laenen, 2017; Todts \& Van Meir, 2011). De meest voorgeschreven middelen zijn benzodiazepines, antidepressiva en antipsychotica. Het gebruik van psychofarmaca bij gedetineerden zou volgens Todts en Van Meir (2011) driemaal zo hoog zijn als in de algemene Belgische bevolking, wat mogelijk een indicatie is voor de aanwezigheid van veel psychische klachten. Anderzijds kunnen deze hoge prevalentiecijfers (mede) te wijten zijn aan voorschrijfpraktijken van gevangenisartsen. In hoeverre deze voorschriften passend zijn, is onbekend, al blijkt uit buitenlands onderzoek dat psychoactieve medicatie vaak als eerste behandeloptie wordt aangewend in penitentiaire settings (Hassan e.a., 2016). Een potentiële verklaring hiervoor is dat zorgverleners onvoldoende tijd en middelen hebben voor niet-farmacologische, psychotherapeutische interventies. Verder blijkt dat van alle gedetineerden in België die verboden middelengebruik tijdens de detentieperiode rapporteren, meer dan de helft (57\%) eveneens psychofarmaca krijgt voorgeschreven (Favril \& Vander Laenen, 2017). Dit kan mogelijk de vaak gerapporteerde comorbiditeit bij druggebruikende gedetineerden illustreren (Butler e.a., 2011; Indig e.a., 2016), waarbij de psychopathologie farmacologisch wordt behandeld.

\section{Specifieke populaties}

Onderzoeksgegevens naar de (psychische) gezondheid van gedetineerden hebben veelal betrekking op mannen van middelbare leeftijd - de doorsneeconstellatie 
van de gedetineerdenpopulatie (tabel 1). Verschillende subgroepen die afwijken van deze 'prototypische gedetineerde' verdienen echter specifieke aandacht, zoals vrouwelijke en oudere gedetineerden, aangezien studies aantonen dat zij bijzonder precaire populaties vormen voor wat betreft psychische gezondheid (Fazel e.a., 2016; Franke e.a., 2019; Watson e.a., 2004; WHO, 2014).

- Vrouwelijke gedetineerden

Hoewel vrouwen wereldwijd slechts een klein percentage van de totale gevangenisbevolking uitmaken (in België en Nederland zo'n 5\%), blijkt de lichamelijke en psychische problematiek bij deze minderheid disproportioneel groot (Ginn, 2013b; Van den Bergh e.a., 2011). Internationaal onderzoek naar de omvang van psychiatrische stoornissen (Binswanger e.a., 2010; Butler e.a., 2011), psychische klachten (Bronson \& Berzofsky, 2017; Indig e.a., 2016) en psychofarmacagebruik (Farrell MacDonald e.a., 2015; Hassan e.a., 2016) laat zien dat vrouwelijke gedetineerden significant meer psychische problemen rapporteren dan mannen in detentie. De literatuur suggereert dat, deels vanwege deze klinische factoren, vrouwen mogelijk verschillend en harder worden getroffen door een detentie dan mannen (Crewe e.a., 2017; Fedock, 2017; Ginn, 2013b). De scheiding van kinderen als gevolg van de opsluiting en eerdere trauma's staan hier vaak centraal.

Van de gevonden studies naar psychische problemen bij gedetineerden in België en Nederland was het onderzoek in slechts twee gevallen uitsluitend gericht op vrouwen (tabel 2). Slotboom en collega's (2009) vonden dat meer dan de helft (56\%) van 251 vrouwen in Nederlandse penitentiaire inrichtingen een verhoogde score had voor depressieve klachten, en $63 \%$ van hen scoorde boven de grensscore voor een posttraumatische stressstoornis. Verder rapporteerde bijna de helft (43\%) van 397 gedetineerde vrouwen in Nederland een voorgeschiedenis van een behandeling voor psychische klachten (Joosen \& Slotboom, 2015). Geen van deze twee studies kon echter een vergelijking maken tussen gedetineerde mannen en vrouwen; zulke studies zijn zeldzaam in Nederland. ${ }^{9}$ Onderzoeksbevindingen in België (Favril \& Vander Laenen, 2017; Favril e.a., 2017a) tonen wel aan dat, wanneer wordt vergeleken met hun mannelijke tegenhangers in detentie, vrouwen een significant hogere prevalentie laten zien van psychiatrische diagnoses ( 45 vs. $61 \%$ ), ernstige psychologische distress (36 vs. $52 \%$ ) en het gebruik van psychofarmaca (34 vs. 56\%), maar niet qua druggebruik (35 vs. 33\%). Samenvattend kunnen we stellen dat vrouwelijke gedetineerden een (bijzonder) kwetsbare populatie vormen, hetgeen reeds uitvoerig werd aangekaart in zowel België (Nuytiens, 2017) als Nederland (Slotboom \& Bijleveld, 2007). Ook op internationaal niveau worden de specifieke behoeften van vrouwen in detentie erkend door de zogenaamde Bangkok Rules van de Verenigde Naties, waarin wordt gepleit voor een genderspecifieke invulling van detentie (UNODC, 2014).

9 Nederlands onderzoek dat zowel mannen als vrouwen includeert ( $\mathrm{N}=3$ ) betreft voornamelijk dossierstudies naar suïcide in detentie (Blaauw \& Kerkhof, 1999; Duijst e.a., 2012). Eén andere studie (Oliemeulen e.a., 2009) onderzocht problematisch middelengebruik bij mannen en vrouwen in het jaar voorafgaand aan hun detentie. 
- Oudere gedetineerden

Een tweede specifieke (minderheids)groep betreft oudere gedetineerden. In de literatuur worden gedetineerden reeds als 'ouder' gedefinieerd vanaf de leeftijd van 50 of 55 jaar, en zij vormen de snelst groeiende demografische groep binnen gevangenispopulaties in vele westerse landen (Stürup-Toft e.a., 2018; WHO, 2014). Internationale wetenschappelijke studies suggereren dat oudere gedetineerden meer lichamelijke en psychische gezondheidsproblemen ervaren dan zowel leeftijdsgenoten in de vrije samenleving als jongere gedetineerden (Di Lorito e.a., 2018; Fazel e.a., 2001b; Haesen e.a., 2019; Greene e.a., 2018; Munday e.a., 2019). Bij 50 tot $60 \%$ van oudere gedetineerden lijkt sprake te zijn van een (diagnosticeerbare) psychiatrische stoornis (Hayes e.a., 2012; Kingston e.a., 2011). Dertig procent van hen zou aan de criteria voor een klinische depressie voldoen - vijf keer hoger dan bij personen van gelijke leeftijd in de algemene bevolking - waarvan het merendeel echter onbehandeld blijft (Fazel e.a., 2001a).

Geen van de gevonden Belgische en Nederlandse studies richtte zich specifiek op oudere gedetineerden. Hoewel eerder kwalitatief onderzoek werd uitgevoerd naar de detentiebeleving van oudere gedetineerden (Humblet \& Decorte, 2013; Zoutendijk, 2009), ontbreken tot op vandaag kwantitatieve gegevens over de psychische gezondheid van oudere gedetineerden in België en Nederland. Tegelijkertijd wordt beargumenteerd dat gevangenisregimes niet ontworpen zijn met ouderen in gedachten, en dus niet of minder aangepast zijn aan de multipele (en vaak complexe) behoeften die oudere gedetineerden ervaren (Ginn, 2012a; Humblet, 2017). Gegeven de vergrijzing van de gevangenisbevolking is meer (academische en beleidsmatige) aandacht voor de specifieke behoeften van oudere gedetineerden dus van groot belang (UNODC, 2009; Williams e.a., 2012).

\section{Suïcidaliteit}

Conform bevindingen in de algemene bevolking (Chesney e.a., 2014; Gili e.a., 2019; Hoertel e.a., 2015) hebben gedetineerden met psychische problemen een sterk verhoogd risico op suïcide, tijdens de detentieperiode (Baillargeon e.a., 2009; Fazel e.a., 2013; Rivlin e.a., 2010) als kort na de invrijheidstelling (Borschmann e.a., 2017; Pratt e.a., 2010). Internationaal vormt suïcide een van de belangrijkste doodsoorzaken binnen de gevangenismuren, goed voor 30-50\% van alle overlijdens (Fazel \& Baillargeon, 2011; Stürup-Toft e.a., 2018). Een recente studie die gegevens analyseerde van 24 landen vond dat het suïcidecijfer bij mannen in detentie driemaal hoger is ten opzichte van de vrije samenleving, en negenmaal hoger bij gedetineerde vrouwen ${ }^{10}$ (Fazel e.a., 2017a). Hoewel psychische problemen een belangrijke rol spelen in de etiologie van suïcide, dient ook rekening te worden gehouden met de detentiecontext. De verhoogde suïcidecijfers in detentie worden namelijk verklaard vanuit de blootstelling van kwetsbare

10 In absolute cijfers betreft het merendeel van alle suïcides in detentie mannen, wat weinig verwonderlijk is gezien de overwegend mannelijke gevangenisbevolking (tabel 1). Hoewel mannen vaker dan vrouwen overlijden door suïcide in de vrije samenleving, zijn de relatieve suïcidecijfers in detentie vrijwel gelijk voor beide geslachten. Wanneer wordt vergeleken met de algemene bevolking van hetzelfde geslacht en vergelijkbare leeftijd zien we dat gedetineerde vrouwen een proportioneel hoger suïciderisico kennen dan hun mannelijke tegenhangers. 
personen (onder meer gekenmerkt door psychiatrische stoornissen en druggebruik) aan de ontberingen en stressoren die eigen zijn aan de penitentiaire context (Favril \& Liem, 2019; Favril \& Vander Laenen, 2015; 2018a). Belangrijk is verder dat suïcidaal gedrag in detentie ook een significante impact heeft op de psychische gezondheid van medegedetineerden die hiermee worden geconfronteerd (Hales e.a., 2015).

Drie studies hebben suïcide onder gedetineerden in België en Nederland onderzocht (tabel 2). In een recent dossieronderzoek werden alle suïcides in de Belgische gevangenissen geanalyseerd die tijdens de periode 2000-2016 plaatsvonden (Favril e.a., 2018). Gedurende deze zeventienjarige onderzoeksperiode overleden 262 gedetineerden door suïcide in detentie; een derde van alle sterfgevallen in detentie die in dit tijdsbestek werden gedocumenteerd. De resultaten van deze studie komen sterk overeen met twee eerdere onderzoeken die 95 (Blaauw \& Kerkhof, 1999) en 92 (Duijst e.a., 2012) suïcides bestudeerden in Nederlandse gevangenissen, respectievelijk voor de periodes 1987-1998 en 2005-2012. Uit deze drie dossieronderzoeken (met een totaal van 449 suïcides) blijkt dat de 'prototypische suïcidepleger' een ongehuwde man met de Belgische/Nederlandse nationaliteit van 34 tot 37 jaar oud is, die vanwege een geweldsdelict werd opgesloten. Het percentage gedetineerden met een eerdere suïcidepoging (42 tot 54\%) en een psychiatrische stoornis ( 83 tot $87 \%$ ) blijkt sterk verhoogd onder diegenen die suïcide plegen in detentie. De periode kort na opsluiting, een overplaatsing naar een andere gevangenis en justitiële gebeurtenissen (zoals de oplegging van een lange straf) vormen belangrijke risicofactoren voor suïcide. Het merendeel van alle suïcides vindt plaats op de eigen cel van de gedetineerde, in afwezigheid van een celgenoot, door middel van verhanging (Blaauw \& Kerkhof, 1999; Duijst e.a., 2012; Favril e.a., 2018).

Niet alleen suïcides vormen een reden tot bezorgdheid. Buitenlands onderzoek laat zien dat een derde van alle gedetineerden ooit suïcide overwoog in het leven en dat een op vijf ooit een suïcidepoging ondernam, al dan niet tijdens een periode van detentie (Indig e.a., 2016; Larney e.a., 2012). In België vindt men vergelijkbare cijfers; in Nederland is dit tot op heden niet onderzocht (tabel 2). De prevalentie van suïcidale gedachten en suïcidepogingen gedurende de levensloop bedraagt respectievelijk $44 \%$ en $22 \%$ bij gedetineerden in vijftien Vlaamse gevangenissen, met significant hogere cijfers bij gedetineerde vrouwen dan mannen (Favril e.a., 2017b). Uit dit Belgische onderzoek blijkt verder dat zowel importfactoren (psychiatrische stoornissen en eerdere suïcidepogingen) als deprivatiekenmerken (weinig gepercipieerde autonomie, veiligheid en sociale ondersteuning, alsook een gebrek aan zinvolle tijdsbesteding) belangrijke determinanten zijn voor het ervaren van suïcidale gedachten tijdens de detentieperiode (Favril e.a., 2017c). 


\section{Discussie: implicaties voor het beleid en de praktijk}

De prevalentie van psychische gezondheidsproblemen bij gedetineerden in België en Nederland is hoog (voor een samenvatting, zie box 1). Over het algemeen worden in beide landen overeenkomstige cijfers teruggevonden in de literatuur, al zijn eenduidige vergelijkingen niet steeds mogelijk vanwege methodologische verschillen tussen de studies (zie noot 6). Wetenschappelijk onderzoek in de Lage Landen toont verder aan dat gedetineerden met psychische problemen een verhoogd risico lopen op suïcide. Vanuit het oogpunt van de volksgezondheid vormt de (onevenredig) hoge prevalentie van psychische gezondheidsproblemen bij gedetineerden zowel een uitdaging als een kans (WHO, 2014).

\section{Box 1. De psychische gezondheid van gedetineerden}

In het Nederlandse en Belgische gevangeniswezen kampen veel gedetineerden met psychische problemen. Verschillende Nederlandse studies tonen onafhankelijk van elkaar aan dat bij 30 tot $40 \%$ van de gedetineerden in de reguliere penitentiaire inrichtingen sprake is van problematisch druggebruik. Tevens heeft ongeveer $80 \%$ ooit te maken gehad met een psychiatrische stoornis en heeft minstens de helft tijdens de detentie een psychiatrische stoornis (inclusief verslaving). Psychische klachten komen frequent voor, vooral tijdens de eerste fase van detentie, en nemen met verloop van tijd af. Uit grootschalig onderzoek bij gedetineerden in België blijkt dat bijna de helft (46\%) ooit formeel werd gediagnosticeerd met een psychiatrische stoornis. Tijdens de detentie rapporteert een derde van de gedetineerden ernstige psychische klachten (37\%), illegaal druggebruik (30 tot $35 \%$ ) en het gebruik van voorgeschreven psychofarmaca (36 tot 38\%). Samenvattend kunnen we stellen dat de omvang van psychische gezondheidsproblemen bij gedetineerden in zowel Nederland als België onevenredig hoog is ten opzichte van de algemene samenleving, zonder opmerkelijke verschillen tussen beide landen. Deze gedetineerden hebben een sterk verhoogd risico op ongunstige uitkomsten, zoals suïcide. Onze bevindingen benadrukken het belang van effectieve preventiemaatregelen en goede zorg in detentie, alsook na de vrijlating.

\section{Uitdagingen: detectie en behandeling}

Hoewel de prevalentie van psychische problemen bij gedetineerden hoog is, worden ze vaak niet geïdentificeerd tijdens de detentieperiode of blijven ze onbehandeld (Birmingham, 2003; Jakobowitz e.a., 2017; Senior e.a., 2013; Simpson \& Jones, 2018). In dit opzicht dient het belang van vroegtijdige signalering te worden benadrukt - gedetineerden met een zorgbehoefte kunnen op deze manier in een vroeg stadium worden verbonden met geïndiceerde hulpverlening (Forrester e.a., 2018; Kolodziejczak \& Sinclair, 2018; Nicholls e.a., 2018). Verschillende gevalideerde screeningsinstrumenten om psychiatrische morbiditeit bij gedeti- 
neerden te detecteren zijn reeds voorhanden (Martin e.a., 2013; SAMHSA, 2015) en worden idealiter ingebed in een meer omvattend geheel, zoals een doorverwijzing naar beschikbare hulpverlening wanneer de screening op de aanwezigheid van bepaalde symptomen wijst. In deze context ontwikkelden Soyez en collega's (2010) een aangepast protocol voor de screening en assessment van psychiatrische stoornissen en middelenmisbruik bij nieuw aangemelde gedetineerden in Belgische gevangenissen. In Belgische en Nederlandse gevangenissen is zo'n systematische en gestandaardiseerde screeningsprocedure tot op heden echter nog niet geïmplementeerd. Minimaal zou, wanneer een persoon in de gevangenis aankomt, sprake moeten zijn van een uitgebreide gezondheidsintake met specifieke aandacht voor psychische problemen. Het individuele zorgplan dat hieruit volgt, vormt idealiter de basis voor verdere multidisciplinaire hulpverlening.

Wetenschappelijk onderzoek wijst op de noodzaak (NICE, 2017) en effectiviteit (Fazel e.a., 2016; Johnson e.a., 2019; Martin e.a., 2012; Morgan e.a., 2012) van psychologische hulpverlening aan gedetineerden met psychische gezondheidsproblemen. Het aanbieden van passende geestelijke gezondheidszorg vormt echter geen sinecure in detentie (Ginn, 2012b; Kolodziejczak \& Sinclair, 2018; Mills \& Kendall, 2018; Van den Ameele, 2014). Uitdagingen in dit opzicht betreffen onder andere (1) de complexiteit van de psychiatrische problematiek bij gedetineerden, (2) de gevangeniscontext zelf, die gericht is op veiligheid en controle, en daarmee als 'antitherapeutisch' kan worden bestempeld, en (3) het feit dat (geestelijke) gezondheidszorg niet de primaire focus vormt binnen de detentiecontext, waardoor dit aanbod gemakkelijk onder druk komt te staan. Naast een structureel tekort aan hulpverlening (Favril e.a., 2017a) betreft een andere uitdaging de onzekerheid over de mogelijke duur van een begeleiding. Dit is onder meer te wijten aan het hoge aantal (onverwachte) transfers of vrijlatingen van gedetineerden. Veel gedetineerden in België en Nederland zitten korte straffen uit, of zitten in voorlopige hechtenis, waardoor de beschikbare tijd voor een therapeutische interventie vaak beperkt is en het opbouwen van een vertrouwensrelatie niet altijd vanzelfsprekend is.

\section{Kansen}

Ondanks voornoemde uitdagingen vormt het inzetten op de psychische gezondheid van gedetineerden een belangrijke pijler binnen het ruimere penitentiaire beleid. De gevangenis biedt immers de mogelijkheid om een groep individuen te bereiken die in de vrije samenleving regelmatig tussen de mazen van de (gespecialiseerde) hulpverlening valt (Forrester e.a., 2018; Ginn, 2013a; WHO, 2014). Voor deze personen biedt de gevangenis een (eerste) mogelijkheid tot diagnose, begeleiding en behandeling die ze niet zouden ontvangen buiten de muren van de gevangenis. Zo blijkt bijvoorbeeld uit de evaluatie van de Centrale Aanmeldingspunten Drugs in de Belgische gevangenissen dat een derde van de cliënten in het verleden nog geen begeleiding of behandeling had ontvangen voor hun drugspro- 
blematiek (Vandevelde e.a., 2016). ${ }^{11}$ Hiermee biedt de detentieperiode een belangrijke kans om de psychische gezondheid bij een kwetsbare populatie te verbeteren. Recente literatuur suggereert bovendien aanknopingspunten voor effectieve interventies tijdens de detentieperiode, maar ook voor na de vrijlating met oog op de continuïteit van zorg (Hopkin e.a., 2018; Kouyoumdjian e.a., 2015; Shaw e.a., 2017). Dit is belangrijk omdat psychische problemen de kans op agressief gedrag tijdens de detentie (Fazel e.a., 2016) en criminele recidive na vrijlating (Chang e.a., 2015; Hakansson \& Berglund, 2012) significant verhogen. Met een goede en effectieve penitentiaire zorg zijn dan ook niet alleen de gedetineerden zelf gebaat, maar evenzeer de veiligheid in de gevangenissen en de samenleving in brede zin voor wat betreft zorgkosten, recidive en openbare veiligheid (Kinner \& Wang, 2014).

\section{Verantwoordelijkheid en zelfredzaamheid}

In het huidige discours staan strenger straffen en de focus op vergelding en genoegdoening vaak centraal (Beyens e.a., 2014). In het verlengde hiervan wordt bij de uitvoering van de vrijheidsberovende straf steeds meer nadruk gelegd op agency en de eigen verantwoordelijkheid van gedetineerden. Hoewel het stimuleren van zelfredzaamheid een goed streven is, is dit wellicht niet voor iedereen even haalbaar (Vander Beken, 2017). Gedetineerden met psychische problemen kunnen meer moeite hebben met de beoogde zelfredzaamheid en kunnen door hun gezondheidsproblemen minder goed in staat zijn om 'gewenst' gedrag te vertonen. Onze resultaten laten zien dat men in detentie met een kwetsbare groep te maken heeft, waarbij (ernstige) psychische problemen geen uitzondering zijn. Naast de focus op agency, is het van belang om niet uit het oog te verliezen dat een deel van de gedetineerden dusdanige problemen ervaart dat zij meer aandacht, begeleiding en zorg nodig hebben voordat zij überhaupt in staat zullen zijn om tot zelfredzaamheid en (gedrags)verandering te komen.

\section{Methodologische beperkingen en aanbevelingen}

Door middel van een systematisch literatuuronderzoek werden 24 empirische studies geïdentificeerd die in de afgelopen twee decennia de psychische gezondheid en suïcidaliteit van gedetineerden in België en Nederland onderzochten. Hoewel de laatste jaren een duidelijke positieve trend geobserveerd kan worden voor wat betreft wetenschappelijk onderzoek naar dit thema in de Lage Landen, signaleren we ook enkele lacunes en methodologische beperkingen. Zo hanteren slechts twee studies, die beide data gebruiken van het grootschalige Prison Project, een longitudinaal onderzoeksdesign (Beijersbergen e.a., 2014; Brons e.a., 2013). De overige studies zijn crosssectioneel en beschrijvend van aard. Hoewel deze studies belangrijke informatie verschaffen over de psychische gezondheid van

11 Een recente Belgische studie, gepubliceerd nadat het huidige literatuuronderzoek werd voltooid, toont aan dat bijna de helft (47\%) van alle gedetineerden die druggebruik tijdens de detentieperiode rapporteren geen ervaring had met enige vorm van verslavingszorg voorafgaand aan hun opsluiting (Favril \& Vander Laenen, 2018b). 
gedetineerden, kunnen op basis van deze studies geen uitspraken worden gedaan over eventuele temporele - laat staan causale - verbanden. Indien we inzicht willen krijgen in hoeverre detentie een effect heeft op (het verloop van) de psychische gezondheid is, zeker in België, toekomstig prospectief onderzoek noodzakelijk, waarbij gedetineerden op meerdere meetmomenten worden bevraagd.

Daarnaast verschilde de kwaliteit van de methode om psychische problemen vast te stellen nogal tussen de studies. Een aanzienlijk aantal hanteerde bijvoorbeeld (anonieme) vragenlijsten om psychische klachten, druggebruik en suïcidaliteit in kaart te brengen. Zelfrapportage, al dan niet retrospectief, is echter vatbaar voor geheugeneffecten, herinterpretatie en sociaal wenselijke antwoorden. Gezien de gevoelige aard van psychische problemen is het bovendien mogelijk dat er sprake was van onderrapportage. Dossierstudies kunnen in dit opzicht een meer objectieve oplossing bieden, al zijn de onderzoekers in dit geval volledig afhankelijk van de kwantiteit en kwaliteit van de gedocumenteerde gegevens (die initieel niet voor wetenschappelijke doeleinden worden gerapporteerd). Idealiter worden (diagnostische) interviews uitgevoerd door getrainde clinici; deze methode wordt als de 'gouden standaard' gezien bij het vaststellen van psychische problemen. Een dergelijke aanpak vergt echter aanzienlijk veel tijd en middelen, wat niet steeds haalbaar is wanneer een grote steekproef wordt beoogd.

Qua onderzoekspopulaties kunnen eveneens aanbevelingen worden geformuleerd. Een groot aantal van de geïncludeerde studies had namelijk betrekking op afgebakende steekproeven. Zo richtte het merendeel van het Nederlandse onderzoek zich op de psychische gezondheid van (recent opgesloten) gedetineerden in huizen van bewaring, waardoor nog relatief weinig kennis beschikbaar is over diegenen die zijn veroordeeld tot een (lange) gevangenisstraf. Verder blijft vergelijkend onderzoek tussen mannelijke en vrouwelijke gedetineerden sterk onderbelicht in Nederland, waar de overgrote meerderheid van de studies uitsluitend mannelijke (of vrouwelijke) steekproeven betreft. Hierdoor kunnen geen betekenisvolle vergelijkingen worden gemaakt tussen gedetineerde mannen en vouwen. Ten slotte is zowel in België als in Nederland tot op heden geen kwantitatief onderzoek uitgevoerd naar de psychische gezondheid van oudere gedetineerden. Om de huidige kennis over psychische gezondheidsproblemen bij gedetineerden te vergroten, is onderzoek naar deze onderbelichte subgroepen geboden.

Afsluitend vormt het systematisch monitoren van de psychische gezondheid van alle gedetineerden (ongeacht hun detentieduur, geslacht of leeftijd) een belangrijk beleidsinstrument binnen het gevangeniswezen (Fazel e.a., 2016; Verdot e.a., 2015). Op deze manier kan men de psychische gezondheid(sbehoeften) van gedetineerden in kaart brengen, de geestelijke gezondheidszorg hierop afstemmen en het penitentiaire beleid informeren. Bij herhaalde metingen kunnen bovendien ontwikkelingen in de tijd worden onderzocht en mogelijke interventies worden geëvalueerd. Een voorbeeld van een good practice is in dit opzicht het Australian Institute of Health and Welfare, dat al sinds 2009 de (psychische) gezondheid van gedetineerden op nationaal niveau in kaart brengt (AIHW, 2015). Specifiek voor druggebruik in detentie ontwikkelde het Europees Waarnemingscentrum voor Drugs en Drugsverslaving (EMCDDA) recent nog een uniforme vragenlijst die over landsgrenzen heen kan worden geïmplementeerd (Montanari e.a., 2017). In 
een ideale wereld wordt in de toekomst eenzelfde gestandaardiseerd instrument aangewend in België en Nederland, om zo grootschalig vergelijkend onderzoek mogelijk te maken.

\section{Conclusie}

Dit systematische overzicht van wetenschappelijke studies toont ondubbelzinnig aan dat gedetineerden in psychiatrisch opzicht geen 'gezonde' populatie betreffen. Gedetineerden in de Belgische en Nederlandse gevangenissen worden, als groep, gekenmerkt door een slechte psychische gezondheid; een bevinding die consistent is met veelvuldig buitenlands onderzoek. De detentieperiode biedt evenwel een uitgelezen kans om psychische gezondheidsproblemen aan te pakken, wat zowel de gedetineerden als de ruimere gemeenschap ten goede komt. Uiteindelijk is het voor de overgrote meerderheid van gedetineerden de bedoeling dat ze na hun detentie opnieuw aansluiting vinden in de maatschappij. Een ontoereikende penitentiaire zorg kan ongunstige gevolgen hebben voor de psychische gezondheid van gedetineerden, niet enkel binnen, maar ook later buiten de gevangenismuren. Het adequaat aanpakken van psychische problemen tijdens de detentieperiode kan in positieve zin bijdragen tot een succesvolle terugkeer van gedetineerden in de samenleving, alsook de volksgezondheid ten goede komen.

\section{Literatuur $^{12}$}

Aebi, M.F., Tiago, M.M., Berger-Kolopp, L. \& Burkhardt, C. (2017). SPACE I - Council of Europe annual penal statistics: prison populations. Survey 2016. Strasbourg: Council of Europe.

AIHW. (2015). The health of Australia's prisoners 2015. Canberra: Australian Institute of Health and Welfare.

Ameele, R. van den (2014). Psychologische hulp aan gedetineerden: een evaluatie van vijf jaar CGG Eclips binnen de gevangenismuren. Fatik, 31(144), 24-28.

Andersen, H.S. (2004). Mental health in prison populations. Acta Psychiatrica Scandinavica, 110(S424), 5-59.

Armour, C. (2012). Mental health in prison: a trauma perspective on importation and deprivation. International Journal of Criminology and Sociological Theory, 5(2), 886-894.

Baillargeon, J., Penn, J.V., Thomas, C.R., Temple, J.R., Baillargeon, G. \& Murray, O.J. (2009). Psychiatric disorders and suicide in the nation's largest state prison system. Journal of the American Academy of Psychiatry and the Law, 37(2), 188-193.

${ }^{*}$ Bak, R.R. den, Popma, A., Nauta-Jansen, L., Nieuwbeerta, P. \& Jansen, J.M. (2018). Inventarisatie van psychosociale criminogene factoren en neurobiologische kenmerken bij mannelijke gedetineerden. Den Haag: WODC.

Baranyi, G., Cassidy, M., Fazel, S., Priebe, S. \& Mundt, A.P. (2018). Prevalence of posttraumatic stress disorder in prisoners. Epidemiologic Reviews, 40(1), 134-145.

Bebbington, P., Jakobowitz, S., McKenzie, N., Killaspy, H., Iveson, R., Duffield, G. e.a. (2017). Assessing needs for psychiatric treatment in prisoners: 1 . Prevalence of disorder. Social Psychiatry and Psychiatric Epidemiology, 52(2), 221-229. 
*Beijersbergen, K.A., Dirkzwager, A.J.E., Eichelsheim, V.I., Laan, P.H. van der \& Nieuwbeerta, P. (2014). Procedural justice and prisoners' mental health problems: a longitudinal study. Criminal Behaviour and Mental Health, 24(2), 100-112.

Bennett, T., Holloway, K. \& Farrington, D. (2008). The statistical association between drug misuse and crime: a meta-analysis. Aggression and Violent Behavior, 13(2), 107-118.

Bergh, B.J. van den, Gatherer, A., Fraser, A. \& Moller, L. (2011). Imprisonment and women's health: concerns about gender sensitivity, human rights and public health. Bulletin of the World Health Organization, 89(9), 689-694.

Beyens, K., Dirkzwager, A. \& Korf, D. (2014). Detentie en gevolgen van detentie: onderzoek in Nederland en België. Tijdschrift voor Criminologie, 56(2), 3-30.

Binswanger, I.A., Merrill, J.O., Krueger, P.M., White, M.C., Booth, R.E. \& Elmore, J.G. (2010). Gender differences in chronic medical, psychiatric, and substance-dependence disorders among jail inmates. American Journal of Public Health, 100(3), 476-482.

Birmingham, L. (2003). The mental health of prisoners. Advances in Psychiatric Treatment, 9(3), 191-201.

*Blaauw, E. \& Kerkhof, A.J.F.M. (1999). Suïcides in detentie. Amsterdam: Vrije Universiteit Amsterdam.

Borschmann, R., Thomas, E., Moran, P., Carroll, M., Heffernan, E., Spittal, M.J. e.a. (2017). Self-harm following release from prison: a prospective data linkage study. Australian and New Zealand Journal of Psychiatry, 51(3), 250-259.

*Brons, A., Dirkzwager, A., Beijersbergen, K., Reef, J. \& Nieuwbeerta, P. (2013). Psychische klachten bij mannelijke gedetineerden: prevalentie en risicofactoren. Tijdschrift voor Criminologie, 55(3), 241-258.

Bronson, J. \& Berzofsky, M. (2017). Indicators of mental health problems reported by prisoners and jail inmates, 2011-12. Washington, DC: Bureau of Justice Statistics.

*Bulten, E. \& Nijman, H. (2009). Veel psychiatrische stoornissen onder gedetineerden op reguliere afdelingen van penitentiaire inrichtingen. Nederlands Tijdschrift voor Geneeskunde, 153:A634.

Bulten, B.H., Tilburg, W. van \& Limbeek, J. van (1999). Psychopathologie bij gedetineerden. Tijdschrift voor Psychiatrie, 41(10), 575-585.

Butler, T., Indig, D., Allnutt, S. \& Mamoon, H. (2011). Co-occurring mental illness and substance use disorder among Australian prisoners. Drug and Alcohol Review, 30(2), 188-194.

Butler, T., Andrews, G., Allnutt, S., Sakashita, C., Smith, N.E. \& Basson, J. (2006). Mental disorders in Australian prisoners: a comparison with a community sample. Australian and New Zealand Journal of Psychiatry, 40(3), 272-276.

Carpentier, C., Royuela, L., Noor, A. \& Hedrich, D. (2012). Ten years of monitoring illicit drug use in prison populations in Europe: issues and challenges. The Howard Journal of Criminal Justice and Behavior, 51(1), 37-66.

Chang, Z., Larsson, H., Lichtenstein, P. \& Fazel, S. (2015). Psychiatric disorders and violent reoffending: a national cohort study of convicted prisoners in Sweden. Lancet Psychiatry, 2(10), 891-900.

Chesney, E., Goodwin, G.M. \& Fazel, S. (2014). Risks of all-cause and suicide mortality in mental disorders: a meta-review. World Psychiatry, 13(2), 153-160.

Copeland, W.E., Miller-Johnson, S., Keeler, G., Angold, A. \& Costello, E.J. (2007). Childhood psychiatric disorders and young adult crime: a prospective, population-based study. American Journal of Psychiatry, 164(11), 1668-1675.

Crewe, B., Hulley, S. \& Wright, S. (2017). The gendered pains of life imprisonment. British Journal of Criminology, 57(6), 1359-1378. 
Di Lorito, C., Völlm, B. \& Dening, T. (2018). Psychiatric disorders among older prisoners: a systematic review and comparison study against older people in the community. Aging \& Mental Health, 22(1), 1-10.

*Dijksman, A. \& Blaauw, E. (1997). Psychologisch disfunctioneren van gedetineerden. Sancties, 6, 317-327.

Dirkzwager, A.J.E. \& Nieuwbeerta, P. (2018). Psychische problemen tijdens detentie: een overzicht van kernresultaten uit het Prison Project. PROCES, 97(1), 6-17.

Dirkzwager, A.J.E., Nieuwbeerta, P. \& Fiselier, J.P.S. (2009). Onbedoelde gevolgen van vrijheidsstraffen: een literatuurstudie. Tijdschrift voor Criminologie, 51(1), 21-41.

Dolan, K., Wirtz, A.L., Moazen, B., Ndeffo-mbah, M., Galvani, A., Kinner, S.A. e.a. (2016). Global burden of HIV, viral hepatitis, and tuberculosis in prisoners and detainees. Lancet, 388(10049), 1089-1102.

*Duijst, W., Thoonen, E., Gaauw, S. van der \& Korthals, N. (2012). Suïcide in detentie \& EVRM. Apeldoorn: Maklu.

Edgemon, T.G. \& Clay-Warner, J. (2019). Inmate mental health and the pains of imprisonment. Society and Mental Health, 9(1), 33-50.

Farrell MacDonald, S., Keown, L.A., Boudreau, H., Gobeil, R. \& Wardrop, K. (2015). Prevalence of psychotropic medication prescription among federal offenders. Ottawa: Correctional Service of Canada.

Favril, L. \& Liem, M. (2019). Suïcide in penitentiaire inrichtingen. In: C. van Heeringen, A. Kerkhof, G. Portzky \& D. de Beurs (red.). Handboek suïcidaal gedrag (pp. 439-450). Utrecht: de Tijdstroom.

Favril, L. \& Vander Laenen, F. (2015). Suïcidaliteit in detentie: over kwetsbare personen in een stressvolle context. Fatik, 32(148), 13-20.

*Favril, L. \& Vander Laenen, F. (2017). Psychofarmaca en drugsgebruik in Vlaamse gevangenissen. Verslaving, 13(2), 85-97.

Favril, L. \& Vander Laenen, F. (2018a). Suïcidepreventie in de Belgische gevangenissen: een stand van zaken. Neuron, 23(9), 20-23.

Favril, L. \& Vander Laenen, F. (2018b). Predictoren van druggebruik tijdens de detentieperiode: data van 1326 gedetineerden uit 15 Vlaamse gevangenissen. Panopticon, 39(4), 296-312.

*Favril, L., Vander Laenen, F. \& Audenaert, K. (2017a). Psychiatrische morbiditeit bij gedetineerden in Vlaanderen. Panopticon, 38(4), 231-245.

*Favril, L., Vander Laenen, F. \& Audenaert, K. (2017b). Suïcidaal gedrag bij gedetineerden in Vlaanderen: prevalentie en samenhang met psychische distress. Tijdschrift voor Psychiatrie, 59(4), 203-211.

*Favril, L., Vander Laenen, F., Vandeviver, C. \& Audenaert, K. (2017c). Suicidal ideation while incarcerated: prevalence and correlates in a large sample of male prisoners in Flanders, Belgium. International Journal of Law and Psychiatry, 55, 19-28.

${ }^{*}$ Favril, L., Wittouck, C., Audenaert, K. \& Vander Laenen, F. (2018). Suïcide bij gedetineerden in België: een dossierstudie. PROCES, 97(1), 43-59.

Fazel, S. (2018). Synthesizing the evidence on prisoner health - taking stock and moving forward. American Journal of Epidemiology, 187(6), 1137-1139.

Fazel, S. \& Baillargeon, J. (2011). The health of prisoners. Lancet, 377(9769), 956-965.

Fazel, S. \& Danesh, J. (2002). Serious mental disorder in 23000 prisoners: a systematic review of 62 surveys. Lancet, 359(9306), 545-550.

Fazel, S. \& Seewald, K. (2012). Severe mental illness in 33588 prisoners worldwide: systematic review and meta-regression analysis. British Journal of Psychiatry, 200(5), 364-373. 
Fazel, S., Ramesh, T. \& Hawton, K. (2017a). Suicide in prisons: an international study of prevalence and contributory factors. Lancet Psychiatry, 4(12), 946-952.

Fazel, S., Wolf, A. \& Geddes, J.R. (2013). Suicide in prisoners with bipolar disorder and other psychiatric disorders: a systematic review. Bipolar Disorders, 15(5), 491-495.

Fazel, S., Yoon, I.A. \& Hayes, A.J. (2017b). Substance use disorders in prisoners: an updated systematic review and meta-regression analysis in recently incarcerated men and women. Addiction, 112(10), 1725-1739.

Fazel, S., Hope, T., O'Donnell, I. \& Jacoby, R. (2001a). Hidden psychiatric morbidity in elderly prisoners. British Journal of Psychiatry, 179(6), 535-539.

Fazel, S., Hayes, A.J., Bartellas, K., Clerici, M. \& Trestman, R. (2016). Mental health of prisoners: prevalence, adverse outcomes, and interventions. Lancet Psychiatry, 3(9), 871-881.

Fazel, S., Hope, T., O’Donnell, I., Piper, M. \& Jacoby, R. (2001b). Health of elderly male prisoners: worse than the general population, worse than younger prisoners. Age and Ageing, 30(5), 403-407.

Fazel, S., Wolf, A., Chang, Z., Larsson, H., Goodwin, G.M. \& Lichtenstein, P. (2015). Depression and violence: a Swedish population study. Lancet Psychiatry, 2(3), 224-232.

Fedock, G.L. (2017). Women's psychological adjustment to prison: a review for future social work directions. Social Work Research, 41(1), 31-42.

Forrester, A., Till, A., Simpson, A. \& Shaw, J. (2018). Mental illness and the provision of mental health services in prisons. British Medical Bulletin, 127(1), 101-109.

Fovet, T., Geoffroy, P.A., Vaiva, G., Adins, C., Thomas, P. \& Amad, A. (2015). Individuals with bipolar disorder and their relationship with the criminal justice system: a critical review. Psychiatric Services, 66(4), 348-353.

Franke, I., Vogel, T., Eher, R., \& Dudeck, M. (2019). Prison mental healthcare: recent developments and future challenges. Current Opinion in Psychiatry.

Gili, M., Castellvi, P., Vives, M., de la Torre-Luque, A., Almenara, J., Blasco, M.J. e.a. (2019). Mental disorders as risk factors for suicidal behavior in young people: a metaanalysis and systematic review of longitudinal studies. Journal of Affective Disorders, 245, 152-162.

Gillespie, W. (2005). A multilevel model of drug abuse inside prison. Prison Journal, 85(2), 223-246.

Ginn, S. (2012a). Elderly prisoners. BMJ, 345(7879), 24-27.

Ginn, S. (2012b). The challenge of providing prison healthcare. BMJ, 345(7875), 26-28.

Ginn, S. (2013a). Promoting health in prison. BMJ, 346(7910), 19-21.

Ginn, S. (2013b). Women prisoners. BMJ, 346(7891), 22-24.

Gonçalves, L.C., Endrass, J., Rossegger, A. \& Dirkzwager, A.J. (2016). A longitudinal study of mental health symptoms in young prisoners: exploring the influence of personal factors and the correctional climate. BMC Psychiatry, 16:91.

Goomany, A. \& Dickinson, T. (2015). The influence of prison climate on the mental health of adult prisoners: a literature review. Journal of Psychiatric and Mental Health Nursing, 22(6), 413-422.

Gottfried, E.D. \& Christopher, S.C. (2017). Mental disorders among criminal offenders: a review of the literature. Journal of Correctional Health Care, 23(3), 336-346.

Greene, M., Ahalt, C., Stijacic-Cenzer, I., Metzger, L. \& Williams, B. (2018). Older adults in jail: high rates and early onset of geriatric conditions. Health and Justice, 6:3.

Haesen, S., Merkt, H., Imber, A., Elger, B. \& Wangmo, T. (2019). Substance use and other mental health disorders among older prisoners. International Journal of Law and Psychiatry, 62, 20-31. 
Hakansson, A. \& Berglund, M. (2012). Risk factors for criminal recidivism - a prospective follow-up study in prisoners with substance abuse. BMC Psychiatry, 12:111.

Hales, H., Edmondson, A., Davison, S., Maughan, B. \& Taylor, P.J. (2015). The impact of contact with suicide-related behavior in prison on young offenders. Crisis, 36(1), 21-30.

Hassan, L., Senior, J., Webb, R.T., Frisher, M., Tully, M.P., While, D. e.a. (2016). Prevalence and appropriateness of psychotropic medication prescribing in a nationally representative cross-sectional survey of male and female prisoners in England. BMC Psychiatry, 16:346.

Hayes, A.J., Burns, A., Turnbull, P. \& Shaw, J.J. (2012). The health and social needs of older male prisoners. International Journal of Geriatric Psychiatry, 27(11), 1155-1162.

Heidari, E., Dickson, C. \& Newton, T. (2014). An overview of the prison population and the general health status of prisoners. British Dental Journal, 217(1), 15-19.

Hoertel, N., Franco, S., Wall, M.M., Oquendo, M.A., Kerridge, B.T., Limosin, F. e.a. (2015). Mental disorders and risk of suicide attempt: a national prospective study. Molecular Psychiatry, 20(6), 718-726.

Hopkin, G., Evans-Lacko, S., Forrester, A., Shaw, J. \& Thornicroft, G. (2018). Interventions at the transition from prison to the community for prisoners with mental illness: a systematic review. Administration and Policy in Mental Health and Mental Health Services Research, 45(4), 623-634.

Howerton, A., Byng, R., Campbell, J., Hess, D., Owens, C. \& Aitken, P. (2007). Understanding help seeking behaviour among male offenders: qualitative interview study. $B M J$, 334(7588), 303-306.

Humblet, D. (2017). Oudere gedetineerden. In: K. Beyens \& S. Snacken (red.). Straffen: een penologisch perspectief. Antwerpen: Maklu, 475-489.

Humblet, D. \& Decorte, T. (2013). Detentiebeleving door oudere gevangenen in België: een exploratief onderzoek. Panopticon, 34(4), 267-283.

Indig, D., Gear, C. \& Wilhelm, K. (2016). Comorbid substance use disorders and mental health disorders among New Zealand prisoners. Wellington: New Zealand Department of Corrections.

Jablonska, A. \& Meek, R. (2018). 'There was no understanding, there was no care, there was no looking after me': the impact of the prison environment on the mental health of female prisoners. In: A. Mills \& K. Kendall (eds.). Mental health in prisons. London: Palgrave Macmillan, 159-182.

Jakobowitz, S., Bebbington, P., McKenzie, N., Iveson, R., Duffield, G., Kerr, M. e.a. (2017). Assessing needs for psychiatric treatment in prisoners: 2. Met and unmet need. Social Psychiatry and Psychiatric Epidemiology, 52(2), 231-240.

Johnson, J.E., Stout, R.L., Miller, T.R., Zlotnick, C., Cerbo, L.A., Andrade, J.T. e.a. (2019). Randomized cost-effectiveness trial of group interpersonal psychotherapy (IPT) for prisoners with major depression. Journal of Consulting and Clinical Psychology.

*Joosen, K. \& Slotboom, A.M. (2015). Terugblikken op de aanloop: dynamische voorspellers van perioden van detentie gedurende de levensloop van vrouwelijke gedetineerden in Nederland. Tijdschrift voor Criminologie, 57(1), 84-98.

Kessler, R.C., Aguilar-Gaxiola, S., Alonso, J., Chatterji, S., Lee, S., Ormel, J. e.a. (2009). The global burden of mental disorders: an update from the WHO World Mental Health (WMH) Surveys. Epidemiology and Psychiatric Sciences, 18(1), 23-33.

Kingston, P., Le Mesurier, N., Yorston, G., Wardle, S. \& Heath, L. (2011). Psychiatric morbidity in older prisoners: unrecognized and undertreated. International Psychogeriatrics, 23(8), 1354-1360. 
Kinner, S.A. \& Rich, J.D. (2018). Drug use in prisoners: epidemiology, implications, and policy responses. Oxford: Oxford University Press.

Kinner, S.A. \& Wang, E.A. (2014). The case for improving the health of ex-prisoners. American Journal of Public Health, 104(8), 1352-1355.

Kinner, S.A. \& Young, J.T. (2018). Understanding and improving the health of people who experience incarceration: an overview and synthesis. Epidemiologic Reviews, 40(1), 4-11.

*Koeter, M.W.J. \& Luhrman, G.C. (1998). Verslavingsproblematiek bij justitiabele drugverslaafden. Amsterdam: AIAR.

Kolodziejczak, O. \& Sinclair, S.J. (2018). Barriers and facilitators to effective mental health care in correctional settings. Journal of Correctional Health Care, 24(3), 253-263.

Kouyoumdjian, F., Schuler, A., Matheson, F.I. \& Hwang, S.W. (2016). Health status of prisoners in Canada. Canadian Family Physician, 62(3), 215-222.

Kouyoumdjian, F.G., McIsaac, K.E., Liauw, J., Green, S., Karachiwalla, F., Siu, W. e.a. (2015). A systematic review of randomized controlled trials of interventions to improve the health of persons during imprisonment and in the year after release. American Journal of Public Health, 105(4), E13-E33.

Larney, S., Topp, L., Indig, D., O’Driscoll, C. \& Greenberg, D. (2012). A cross-sectional survey of prevalence and correlates of suicidal ideation and suicide attempts among prisoners in New South Wales, Australia. BMC Public Health, 12:14.

Martin, M.S., Colman, I., Simpson, A.I.F. \& McKenzie, K. (2013). Mental health screening tools in correctional institutions: a systematic review. BMC Psychiatry, 13:275.

Martin, M.S., Dorken, S.K., Wamboldt, A.D. \& Wootten, S.E. (2012). Stopping the revolving door: a meta-analysis on the effectiveness of interventions for criminally involved individuals with major mental disorders. Law and Human Behavior, 36(1), $1-12$.

Mills, A. \& Kendall, K. (2018). Care versus custody: challenges in the provision of prison mental health care. In: A. Mills \& K. Kendall (eds.). Mental health in prisons. London: Palgrave Macmillan, 105-129.

Montanari, L., Mravcik, V., Grohmannova, K. \& Royuela, L. (2017). European questionnaire on drug use among prisoners (EQDP). Lisbon: European Monitoring Centre for Drugs and Drug Addiction.

Morgan, R.D., Flora, D.B., Kroner, D.G., Mills, J.F., Varghese, F. \& Steffan, J.S. (2012). Treating offenders with mental illness: a research synthesis. Law and Human Behavior, 36(1), 37-50.

Morgan, V.A., Morgan, F., Valuri, G., Ferrante, A., Castle, D. \& Jablensky, A. (2013). A whole-of-population study of the prevalence and patterns of criminal offending in people with schizophrenia and other mental illness. Psychological Medicine, 43(9), 1869-1880.

Munday, D., Leaman, J., O’Moore, E. \& Plugge, E. (2019). The prevalence of non-communicable disease in older people in prison: a systematic review and meta-analysis. Age and Ageing.

Mundt, A.P., Baranyi, G., Gabrysch, C. \& Fazel, S. (2018). Substance use during imprisonment in low- and middle-income countries. Epidemiologic Reviews, 40(1), 70-81.

NICE. (2017). Mental health of adults in contact with the criminal justice system. London: National Institute for Health and Care Excellence.

Nicholls, T.L., Butler, A., Kendrick-Koch, L., Brink, J., Jones, R. \& Simpson, A.I.F. (2018). Assessing and treating offenders with mental illness. In: M. Ternes, P.R. Magaletta \& M.W. Patry (eds.). The practice of correctional psychology. Cham: Springer, 9-37. 
Nurse, J., Woodcock, P. \& Ormsby, J. (2003). Influence of environmental factors on mental health within prisons: focus group study. BMJ, 327(7413), 480-483.

Nuytiens, A. (2017). Vrouwelijke gedetineerden. In: K. Beyens \& S. Snacken (red.). Straffen: een penologisch perspectief. Antwerpen: Maklu, 491-506.

*Oliemeulen, L., Eijnden, R. van den, Ooyen-Houben, M. van \& Mheen, D. van de (2009). Problematisch middelengebruik onder Nederlandse gedetineerden. Verslaving, 5(2), 3-18.

Opitz-Welke, A., Lehmann, M., Seidel, P. \& Konrad, N. (2018). Medicine in the penal system. Deutsches Arzteblatt International, 115(48), 808-814.

Pratt, D., Appleby, L., Piper, N., Webb, R. \& Shaw, J. (2010). Suicide in recently released prisoners: a case-control study. Psychological Medicine, 40(5), 827-835.

Prince, J.D. \& Wald, C. (2018). Risk of criminal justice system involvement among people with co-occurring severe mental illness and substance use disorder. International Journal of Law and Psychiatry, 58, 1-8.

Prins, S.J. (2014). Prevalence of mental illnesses in US State prisons: a systematic review. Psychiatric Services, 65(7), 862-872.

Reynders, A., Kerkhof, A.J., Molenberghs, G. \& Audenhove, C. van (2016). Risicofactoren en beschermende factoren inzake suïcide in Nederland en Vlaanderen. Tijdschrift voor Psychiatrie, 58(2), 105-113.

Rivlin, A., Hawton, K., Marzano, L. \& Fazel, S. (2010). Psychiatric disorders in male prisoners who made near-lethal suicide attempts: case-control study. British Journal of Psychiatry, 197(4), 313-319.

SAMHSA. (2015). Screening and assessment of co-occurring disorders in the justice system. Rockville: Substance Abuse and Mental Health Services Administration.

Schnittker, J., Massoglia, M. \& Uggen, C. (2012). Out and down: incarceration and psychiatric disorders. Journal of Health and Social Behavior, 53(4), 448-464.

${ }^{*}$ Schoemaker, C. \& Zessen, G. van (1997). Psychische stoornissen bij gedetineerden: een verkennend onderzoek in penitentiair complex Scheveningen. Utrecht: Trimbos-instituut.

*Schreuder, I. \& Veen, M.G. van (2010). Prevalentie van hiv, hepatitis B en hepatitis C bij mannen in detentie in Sittard. Bilthoven: RIVM.

Senior, J., Birmingham, L., Harty, M.A., Hassan, L., Hayes, A.J., Kendall, K. e.a. (2013). Identification and management of prisoners with severe psychiatric illness by specialist mental health services. Psychological Medicine, 43(7), 1511-1520.

Shaw, J., Conover, S., Herman, D., Jarrett, M., Leese, M., McCrone, P. e.a. (2017). Critical time intervention for severely mentally ill prisoners (CrISP): a randomised controlled trial. Health Services and Delivery Research, 5:8.

Simpson, A.I.F. \& Jones, R.M. (2018). Two challenges affecting access to care for inmates with serious mental illness: detecting illness and acceptable services. Canadian Journal of Psychiatry, 63(10), 648-650.

Sirdifield, C., Gojkovic, D., Brooker, C. \& Ferriter, M. (2009). A systematic review of research on the epidemiology of mental health disorders in prison populations: a summary of findings. Journal of Forensic Psychiatry \& Psychology, 20(S1), 78-101.

Slotboom, A.M. \& Bijleveld, C. (2007). Wat er in je hoofd en je hart zit weet niemand: gedetineerde vrouwen in Nederland. Justitiële verkenningen, 3(4), 72-88.

*Slotboom, A.M., Menting, B. \& Bijleveld, C. (2009). Psychisch welbevinden van gedetineerde vrouwen in Nederland. Tijdschrift voor Criminologie, 51(1), 42-57.

Soyez, V., De Wilde, J., Vandevelde, S., Vander Beken, T., Todts, S. \& Broekaert, E. (2010). Screening en assessment van psychiatrische stoornissen in Belgische gevangenissen. Verslaving, 6(1), 41-57. 
Stevens, H., Laursen, T.M., Mortensen, P.B., Agerbo, E. \& Dean, K. (2015). Post-illnessonset risk of offending across the full spectrum of psychiatric disorders. Psychological Medicine, 45(11), 2447-2457.

Stürup-Toft, S., O’Moore, E.J. \& Plugge, E.H. (2018). Looking behind the bars: emerging health issues for people in prison. British Medical Bulletin, 125(1), 15-23.

*Todts, S. \& Meir, J. van (2011). Het gebruik van psychofarmaca in de Belgische gevangenissen. Panopticon, 31(3), 53-55.

UNODC. (2009). Handbook on prisoners with special needs. New York: United Nations.

UNODC. (2014). Handbook on women and imprisonment. New York: United Nations.

*Van Malderen, S., Pauwels, L., Walthoff-Borm, C., Glibert, P. \& Todts, S. (2011). Druggebruik in Belgische gevangenissen: monitoring van gezondheidsrisico's. Brussel: Federale Overheidsdienst Justitie.

Vandebosch, H. (2002). De invloed van persoonlijke achtergrondkenmerken en gevangenisfactoren op de probleemervaring en de aanpassingswijze van Nederlandstalige veroordeelden: een studie in vijf Vlaamse strafinrichtingen. Panopticon, 23(1), 22-43.

Vander Beken, T. (2017). Nederland paradoxland. Sancties, 35(5), 269-276.

Vandevelde, S., Vander Laenen, F., Vanderplasschen, W., Mine, B. \& Maes, E. (2016). Process and outcome study of prison-based registration points (PROSPER). Brussel: BELSPO.

Verdot, C., Godin-Blandeau, E., Gremy, I. \& Develay, A.E. (2015). Monitoring systems and national surveys on prison health in France and abroad. European Journal of Public Health, 25(1), 167-172.

*Vogelvang, B., Burik, A. van, Knaap, L.M. van der \& Wartna, B.S.J. (2003). Prevalentie van criminogene factoren bij mannelijke gedetineerden in Nederland. Den Haag: WODC.

Völlm, B.A., Clarke, M., Herrando, V.T., Seppänen, A.O., Gosek, P., Heitzman, J. \& Bulten, E. (2018). European Psychiatric Association (EPA) guidance on forensic psychiatry: evidence based assessment and treatment of mentally disordered offenders. European Psychiatry, 51, 58-73.

*Vyncke, V., Hanssens, L., Steenberghs, E. \& Willems, S. (2015). Onderzoeksrapport 'Gezondheidsprofiel gedetineerden'. Gent: Universiteit Gent.

Watson, R., Stimpson, A. \& Hostick, T. (2004). Prison health care: a review of the literature. International Journal of Nursing Studies, 41(2), 119-128.

WHO. (2014). Prisons and Health. Geneva: World Health Organization.

Williams, B.A., Stern, M.F., Mellow, J., Safer, M. \& Greifinger, R.B. (2012). Aging in correctional custody: setting a policy agenda for older prisoner health care. American Journal of Public Health, 102(8), 1475-1481.

Wilper, A.P., Woolhandler, S., Boyd, J.W., Lasser, K.E., McCormick, D., Bor, D.H. e.a. (2009). The health and health care of US prisoners: results of a nationwide survey. American Journal of Public Health, 99(4), 666-672.

${ }^{*}$ Wit, M.A.S. de, Segeren, M.W. \& Witteveen, E.J. (2012). OGGZ problematiek en nazorg bij Amsterdamse gedetineerden. Amsterdam: GGD Amsterdam.

Witkowski, M., Hudson, P., Batson, S., Moore, B. \& Mitchell, S. (2017). Systematic review of healthcare use and needs of prisoners. Brussels: KCE.

*Wouters, M., Doekhie, J., Korf, D.J. \& Benschop, A. (2010). Gezondheidsrisicogedrag onder mannelijke gedetineerden. Den Haag: WODC.

Yu, R., Geddes, J.R. \& Fazel, S. (2012). Personality disorders, violence, and antisocial behavior: a systematic review and meta-regression analysis. Journal of Personality Disorders, 26(5), 775-792.

Zoutendijk, A. (2009). Bejaarde gedetineerden in Nederland. PROCES, 88(5), 243-262. 


\section{Appendix Dubbelpublicaties van geïncludeerde studies $(\mathrm{N}=13)$}

Blaauw, E., Kerkhof, A.J. \& Hayes, L.M. (2005). Demographic, criminal, and psychiatric factors related to inmate suicide. Suicide and Life-Threatening Behavior, 35(1), 63-75.

Blaauw, E., Voort, M. van der \& Kerkhof, A.J.F.M. (2000). Bedreigingen, pesterijen en suïcidaliteit in detentie. Tijdschrift voor Psychiatrie, 42(2), 73-83.

Bulten, E., Nijman, H. \& Staak, C. van der (2009). Psychiatric disorders and personality characteristics of prisoners at regular prison wards. International Journal of Law and Psychiatry, 32(2), 115-119.

Bulten, E., Nijman, H. \& Staak, C. van der (2009). Psychological predictors of help needs in male Dutch prisoners. International Journal of Forensic Mental Health, 8(2), 71-80.

Dirkzwager, A.J.E. \& Nieuwbeerta, P. (2018). Mental health symptoms during imprisonment: a longitudinal study. Acta Psychiatrica Scandinavica, 138(4), 300-311.

Favril, L., Wittouck, C., Audenaert, K. \& Vander Laenen, F. (2017). Suïcide in de Belgische gevangenissen, 2000-2016. Gent: Universiteit Gent, IRCP.

Favril, L., Wittouck, C., Audenaert, K. \& Vander Laenen, F. (2019). A 17-year national study of prison suicides in Belgium. Crisis, 40(1), 42-53.

Jans, A., Mariën, D., Vyncke, V. \& De Smet, E. (2017). Hoe is het gesteld met de gezondheid van de gedetineerden in Vlaamse en Brusselse gevangenissen? Fatik, 34(156), 16-21.

Oliemeulen, I., Vuijk, P., Rovers, B. \& Eijnden, R. van den (2007). Problematische alcoholgebruikers, druggebruikers en gokkers in het gevangeniswezen. Den Haag: WODC.

Segeren, M., Wit, M. de, Fassaert, T. \& Popma, A. (2017). Determinants of prisoners' perceived need for care in association with criminal recidivism. Journal of Forensic Psychiatry \& Psychology, 28(4), 477-497.

Slotboom, A.M., Bijleveld, C., Day, S. \& Giezen, A. van (2008). Gedetineerde vrouwen in Nederland: over import- en deprivatiefactoren bij detentieschade. Amsterdam: Vrije Universiteit Amsterdam.

Slotboom, A.M., Kruttschnitt, C., Bijleveld, C. \& Menting, B. (2011). Psychological wellbeing of incarcerated women in the Netherlands: importation or deprivation? Punishment \& Society, 13(2), 176-197.

Todts, S., Glibert, P., Van Malderen, S., Van Huyck, C., Saliez, V. \& Hogge, M. (2009). Druggebruik in Belgische gevangenissen: monitoring van gezondheidsrisico's 2008. Brussel: Federale Overheidsdienst Justitie. 